University of Montana

ScholarWorks at University of Montana

\title{
An Introduced Predator Alters Aleutian Island Plant Communities by Thwarting Nutrient Subsidies
}

John L. Maron

University of Montana - Missoula, john.maron@mso.umt.edu

James A. Estes

Donald A. Croll

Eric M. Danner

Sarah C. Elmendorf

See next page for additional authors

Follow this and additional works at: https://scholarworks.umt.edu/biosci_pubs

Part of the Biology Commons

Let us know how access to this document benefits you.

\section{Recommended Citation}

Maron, John L.; Estes, James A.; Croll, Donald A.; Danner, Eric M.; Elmendorf, Sarah C.; and Buckelew, Stacey L., "An Introduced Predator Alters Aleutian Island Plant Communities by Thwarting Nutrient Subsidies" (2006). Biological Sciences Faculty Publications. 251.

https://scholarworks.umt.edu/biosci_pubs/251

This Article is brought to you for free and open access by the Biological Sciences at ScholarWorks at University of Montana. It has been accepted for inclusion in Biological Sciences Faculty Publications by an authorized administrator of ScholarWorks at University of Montana. For more information, please contact

scholarworks@mso.umt.edu. 


\section{Authors}

John L. Maron, James A. Estes, Donald A. Croll, Eric M. Danner, Sarah C. Elmendorf, and Stacey L. Buckelew 


\title{
AN INTRODUCED PREDATOR ALTERS ALEUTIAN ISLAND PLANT COMMUNITIES BY THWARTING NUTRIENT SUBSIDIES
}

\author{
John L. Maron,,${ }^{1,5}$ James A. Estes, ${ }^{2}$ Donald A. Croll,${ }^{3}$ Eric M. Danner, ${ }^{3}$ Sarah C. Elmendorf, ${ }^{4}$ \\ AND StACEy L. BucKelew ${ }^{3}$ \\ ${ }^{1}$ Division of Biological Sciences, University of Montana, Missoula, Montana 59812 USA \\ ${ }^{2}$ U.S. Geological Survey, Department of Ecology and Evolutionary Biology, University of California, \\ Santa Cruz, California 95060 USA \\ ${ }^{3}$ Department of Ecology and Evolutionary Biology, University of California, Santa Cruz, California 95060 USA \\ ${ }^{4}$ Department of Environmental Science and Policy, University of California, Davis, California 95616 USA
}

\begin{abstract}
The ramifying effects of top predators on food webs traditionally have been studied within the framework of trophic cascades. Trophic cascades are compelling because they embody powerful indirect effects of predators on primary production. Although less studied, indirect effects of predators may occur via routes that are not exclusively trophic. We quantified how the introduction of foxes onto the Aleutian Islands transformed plant communities by reducing abundant seabird populations, thereby disrupting nutrient subsidies vectored by seabirds from sea to land. We compared soil and plant fertility, plant biomass and community composition, and stable isotopes of nitrogen in soil, plants, and other organisms on nine fox-infested and nine historically fox-free islands across the Aleutians. Additionally, we experimentally augmented nutrients on a fox-infested island to test whether differences in plant productivity and composition between fox-infested and foxfree islands could have arisen from differences in nutrient inputs between island types.

Islands with historical fox infestations had soils low in phosphorus and nitrogen and plants low in tissue nitrogen. Soils, plants, slugs, flies, spiders, and bird droppings on these islands had low $\delta^{15} \mathrm{~N}$ values indicating that these organisms obtained nitrogen from internally derived sources. In contrast, soils, plants, and higher trophic level organisms on fox-free islands had elevated $\delta^{15} \mathrm{~N}$ signatures indicating that they utilized nutrients derived from the marine environment. Furthermore, soil phosphorus (but not nitrogen) and plant tissue nitrogen were higher on fox-free than fox-infested islands. Nutrient subsidized fox-free islands supported lush, high biomass plant communities dominated by graminoids. Fox-infested islands were less graminoid dominated and had higher cover and biomass of low-lying forbs and dwarf shrubs. While $\delta^{15} \mathrm{~N}$ profiles of soils and plants and graminoid biomass varied with island size and distance from shore, after accounting for these effects differences between fox-infested and fox-free islands still existed. Fertilization over four years caused a 24-fold increase in graminoid biomass and a shift toward a more graminoid dominated plant community typical of fox-free islands. These results indicate that apex predators can influence plant productivity and composition through complex interaction web pathways involving both top-down forcing and bottom-up nutrient exchanges across systems.
\end{abstract}

Key words: Aleutian Islands; fertilization experiments; food web subsidy; indirect effects; introduced foxes; trophic cascade.

Let it be remembered how powerful the influence of a single introduced tree or mammal has been shown to be.

—Darwin (1859)

\section{INTRODUCTION}

Research on food web dynamics over the last several decades has coalesced around two major conceptual foci. The first of these, stimulated by the classic work of Hairston et al. (1960), Brooks and Dodson (1965), and Paine (1966, 1980), has concerned trophic cas-

Manuscript received 25 March 2005; revised 9 June 2005; accepted 29 June 2005. Corresponding Editor (ad hoc): D. S. Gruner.

${ }^{5}$ E-mail: john.maron@mso.umt.edu cades. Here, research has examined the factors that influence the strength and ubiquity of top-down forcing processes, and in particular the degree to which these interactions influence the abundance, production, and species composition of plants at the base of food webs. Seminal work in aquatic systems has shown unequivocally that top predators can indirectly alter plant productivity by several orders of magnitude (Power et al. 1985, Power 1990, Vanni and Findlay 1990, Carpenter and Kitchell 1993, Estes and Duggins 1995, Menge 1995, Brett and Goldman 1996, Estes et al. 1998, Huryn 1998, Micheli 1999). Yet the strength of these indirect effects can be quite variable (Carpenter and Kitchell 1993, Brett and Goldman 1996) and understanding the sources of this variability continues to be 
the subject of much research (Menge 1997, Pace et al. 1999).

In contrast to the large scale experimental and comparative studies that have taken place in aquatic systems, in terrestrial environments an expanding set of smaller scale experiments have shown that diverse predators, including lizards (Schoener and Spiller 1999), spiders (Gomez and Zamora 1994, Spiller and Schoener 1994, Beckerman et al. 1997, Moran and Hurd 1998, Schmitz 1998, 2003), ants (Dyer and Letourneau 1999), and birds (Marquis and Whelan 1994, Van Bael et al. 2003, but see Gruner 2004) can induce "species cascades." Species cascades occur when predators indirectly affect individual plant biomass, growth, or fecundity as opposed to driving communitylevel changes in primary production. Although the influences of large vertebrates have been difficult to examine in terrestrial ecosystems, larger scale comparative and time-series analyses have strongly suggested similar roles for large predatory mammals (McLaren and Peterson 1994, Ripple et al. 2001, Terborgh et al. 2001). While compelling, the statistical effect sizes in experiments in terrestrial systems have often been smaller than what has been documented in aquatic systems (Shurin et al. 2002), and small scale terrestrial experiments (Borer et al. 2005) have yet to reveal the large community-wide indirect effects that are often the hallmark of aquatic trophic cascades. Whether such effects would commonly be found if larger scale studies (the terrestrial analog to "whole lake" experiments) involving wide-ranging vertebrate apex predators could be feasibly conducted in terrestrial systems remains a matter of debate (Strong 1992, Polis and Strong 1996, Pace et al. 1999, Oksanen and Oksanen 2000, Polis et al. 2000, Schmitz et al. 2000, Halaj and Wise 2001). Unquestioned, however, is the need for additional studies that quantify the strength and routes by which indirect effects of large, mobile predators ramify through terrestrial systems (Duffy 2002, Estes 2005).

A second, and more recent, avenue of research in food web dynamics concerns spatial subsidies. A growing number of studies confirm that ecosystems do not exist independently but instead are spatially coupled, open to the flow of nutrients, energy, and materials between them (Bustamante et al. 1995, Polis et al. 1997, 2004a). Recent research has quantified how subsidies moving into systems influence the structure and dynamics of recipient food webs (Polis and Winemiller 1996, Polis et al. 2004a). Some of the most compelling examples of subsidized food webs come from island systems. Nutrients and materials traveling from highly productive marine systems to less productive insular environments subsidize terrestrial plant (Anderson and Polis 1998, 1999, 2004) and consumer populations (Polis and Hurd 1995, 1996, Rose and Polis 1998, Sánchez-Piñero and Polis 2000, Stapp and Polis 2003), thereby altering the organization of island food webs (Polis and Hurd 1996, Polis et al. 2004b). Although material can be transported by physical processes, it is increasingly appreciated that mobile organisms often play an important role in transporting nutrients between systems (Flecker 1996, Vanni 1996, Ben-David et al. 1998, Post et al. 1998, Kitchell et al. 1999, Schindler et al. 2003). Seabirds are potentially important vectors of nutrients from sea to land on islands throughout the world (Burger et al. 1978, Lindeboom 1984, Bosman and Hockey 1988, Mizutani and Wada 1988, Anderson and Polis 1999, 2004).

Although bottom-up effects of subsidies and topdown effects of predators have often been studied in isolation, the interaction of these two forces can produce particularly powerful effects (Menge 2000, Roemer et al. 2002). Subsidies enable predator or consumer populations to attain larger size than they would otherwise, magnifying their impact on lower trophic levels. For example, many aquatic trophic cascades may owe their strength to the fact that top predators are subsidized by the benthos (Huryn 1998, Schindler and Scheuerell 2002). Similarly, unusually forceful trophic effects can occur when consumer populations are subsidized (Bustamante et al. 1995, Polis and Strong 1996, Jefferies 1999, Riley and Jefferies 2004).

Although subsidies can influence the strength of trophic interactions (DeAngelis 1992, Huxel and McCann 1998), trophic interactions also may regulate nutrient availability (Vanni and Layne 1997, Beard et al. 2002, Moore et al. 2003). Predation on organisms that vector nutrients across ecosystems is a relatively unexplored route by which predators may exert such indirect effects on communities. In this paper we provide evidence to show that introduced arctic foxes (Alopex lagopus) have indirectly altered plant communities in the Aleutian Islands by this process. Specifically, we show that fox predation on seabirds has reduced the delivery of nutrient-rich guano (Hutchinson 1950) by seabirds from ocean to land, and that this has resulted in large community-wide effects on island vegetation as well as direct and indirect consumers of vegetation across the entire 1900-km Aleutian archipelago.

\section{STUdy System}

The Aleutian archipelago consists of a string of $>450$ islands that sit at the confluence between the highly productive North Pacific Ocean and Bering Sea (Gard 1977, McAlister and Favorite 1977). These rugged and isolated islands are treeless; plant communities across the Aleutians are characterized by maritime tundra. There are no mammals native to the Aleutians (Murie 1959). These islands support vast populations of ground-nesting seabirds. Currently 29 species of seabirds totaling an estimated $10 \times 10^{6}$ individuals use the Aleutian Islands for breeding. Historically, the Aleutians supported even greater numbers of seabirds. However, over the last 100-150 years, introduced arctic foxes or Norway rats (Rattus norvegicus) extirpated seabirds (particularly burrow nesters) from most of the 
TABLE 1. Names, sizes, and total seabird species richness and abundance on fox-free and fox-infested islands in the Aleutian archipelago.

\begin{tabular}{|c|c|c|c|c|c|}
\hline Island & $\begin{array}{l}\text { Island } \\
\text { size (ha) }\end{array}$ & $\begin{array}{l}\text { No. seabird } \\
\text { spp. }\end{array}$ & $\begin{array}{l}\text { Total no. } \\
\text { seabirds }\end{array}$ & $\begin{array}{l}\text { Year of fox } \\
\text { introduction }\end{array}$ & $\begin{array}{c}\text { Year of fox } \\
\text { removal }\end{array}$ \\
\hline \multicolumn{6}{|c|}{ Fox-free islands } \\
\hline Buldir & 2032 & 22 & 3548130 & & \\
\hline Chagulak & 898 & 20 & 1695186 & & \\
\hline Vsevidof & 188 & 14 & 121110 & & \\
\hline Aiktak & 133 & 17 & 135393 & & \\
\hline Egg & 68 & 15 & 441929 & & \\
\hline Kaligagan & 62 & 12 & 125811 & & \\
\hline Gibson & 20 & 6 & 8785 & & \\
\hline Ogchul & 15 & 11 & 60766 & & \\
\hline Kohl & 11 & 5 & 8200 & & \\
\hline Mean $\pm \mathrm{SE}$ & $379 \pm 233$ & $14 \pm 1.9$ & $682812 \pm 399909$ & & \\
\hline \multicolumn{6}{|c|}{ Fox-infested islands } \\
\hline Nizki & 805 & 10 & 7378 & 1911 & 1969 \\
\hline Kasatochi & 522 & 18 & 38164 & 1927 & 1984 \\
\hline Davidof & 401 & 15 & 20420 & 1924 & 1924 \\
\hline Tanaklak & 394 & 3 & 172 & 1918 & $<1981$ \\
\hline Kanu & 391 & 5 & 300 & 1916 & $<1981$ \\
\hline Ogangen & 288 & 11 & 37633 & 1929 & $<1938$ \\
\hline Khvostof & 288 & 8 & 6140 & 1924 & $<1936$ \\
\hline Tagadak & 247 & 8 & 574 & 1925 & $<1981$ \\
\hline Tanadak & 17 & 6 & 182 & 1929 & disappeared \\
\hline Mean $\pm \mathrm{SE}$ & $371 \pm 71$ & $9 \pm 1.6$ & $15867 \pm 5289$ & & \\
\hline
\end{tabular}

Notes: For fox-infested islands, the date of fox introduction and the date of fox removal (or approximation) are also shown. Seabird numbers are taken from the U.S. Fish and Wildlife Service Beringian Seabird Colony Catalog, computer database, 2004.

$\sim 100$ islands on which they were introduced (Dall 1874, Murie 1959, Black 1984, Bailey 1993). Fox introductions were motivated by the desire to maintain the North Pacific fur trade following overexploitation of fur seals and sea otters by late in the 19th century (Black 1984). The large colonies of breeding seabirds on the Aleutian Islands provided abundant prey for introduced foxes to support a prosperous fur industry (Ashbrook and Walker 1925). The strong impacts of introduced foxes on seabird populations is still evident today as most islands that historically received foxes maintain much smaller seabird populations than those that never received foxes (U.S. Fish and Wildlife Service 2004). Beginning slowly in 1949 but accelerating rapidly after 1970 , the U.S. Fish and Wildlife Service successfully eradicated foxes from most of the Alaska Maritime National Wildlife Refuge's Aleutian Islands Unit (Byrd et al. 1994). While the extirpation of foxes has allowed for significant recovery of some seabird species (Williams et al. 2003), seabird abundance on the fox-free islands was over an order of magnitude higher, and seabird density was over two orders of magnitude greater than on the fox-infested islands we sampled (Table 1; see Croll et al. 2005). Many seabird species, for example, Tufted Puffins (Fratercula cirrhata; see Plate 1), have been slow to recolonize islands that historically contained foxes due to Allee effects and the low intrinsic rate of increase for many seabird species.

Several attributes of the Aleutian archipelago make it an attractive system for examining the community- wide indirect effects of predators across large spatial scales. First, fox introduction (or lack thereof) was repeated across many islands, enabling a robust contrast between fox-infested and fox-free islands. Second, fox introductions were not targeted for particular island types and the history of introductions is reasonably well known. This facilitates using islands with similar histories of fox introduction as replicates. Third, many of the Aleutian Islands are relatively small, high-latitude floral diversity is relatively low, exotic plant species are rare or absent, and plant species composition is largely invariant among islands across the archipelago. This enables effective sampling and characterization of plant communities across many islands. Fourth, the islands we sampled are climatologically and geologically homogeneous with similar overall soil properties. In particular, and in contrast with most tropicaland temperate-latitude islands, strong rainfall gradients across the archipelago are lacking due to the absence of a prevailing wind direction. Thus, contrasts between fox-free and fox-infested islands were not confounded by major differences in habitat complexity, spatial heterogeneity, or underlying edaphic conditions among islands (J. L. Maron, J. A. Estes, and D. A. Croll, unpublished data).

\section{Methods}

\section{Island sampling}

We took a two-tiered approach to determine the potential influence of introduced foxes on plant com- 


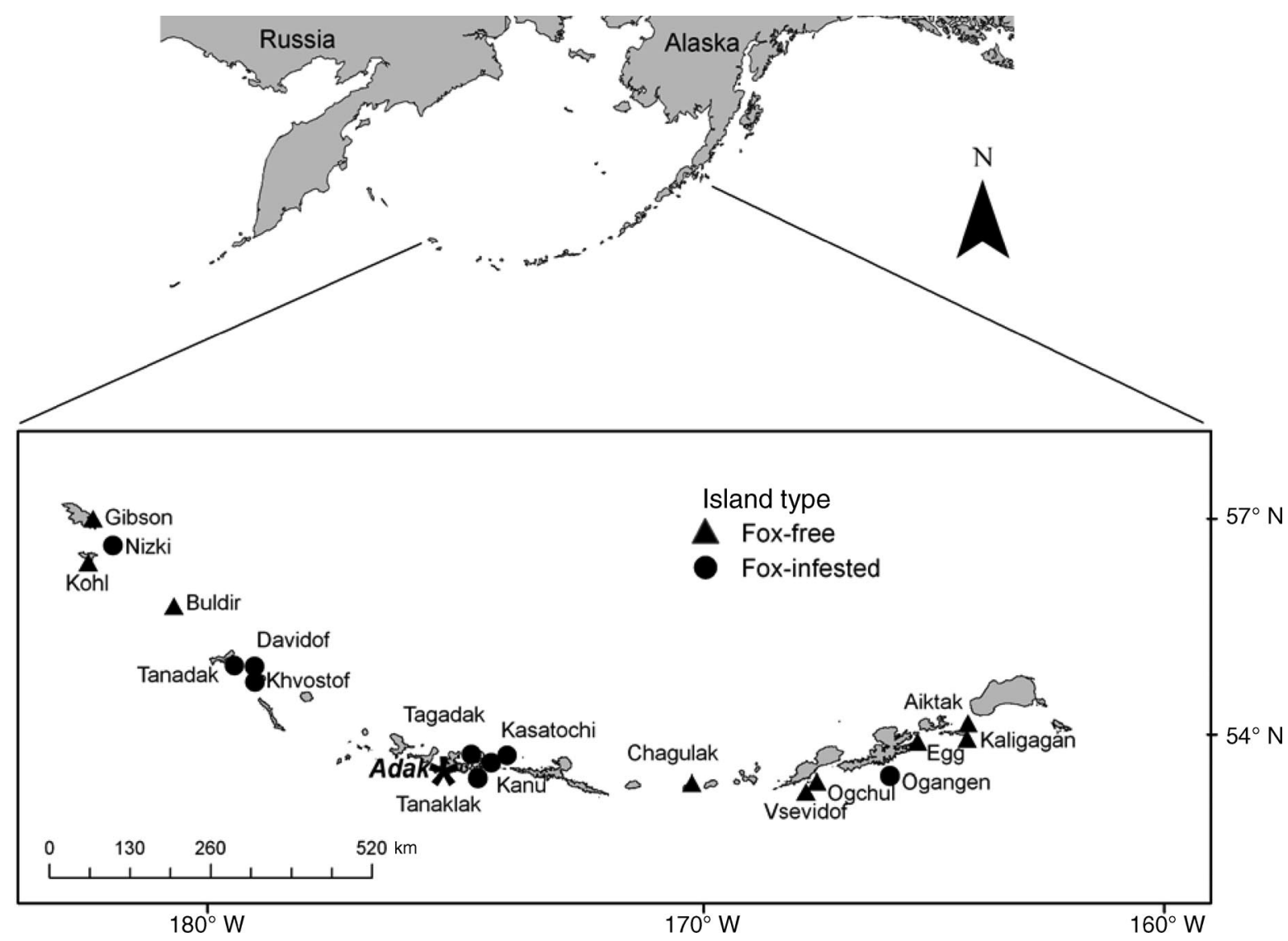

Fig. 1. The Aleutian Archipelago with locations of fox-free (triangles) and fox-infested (circles) sample islands. Adak Island, the fox-infested island where fertilization experiments were conducted, is denoted with a star.

munities and higher trophic level organisms across the Aleutian Islands. First, we determined whether seabirds provided a substantial nutrient subsidy to fox-free islands and whether this subsidy was disrupted on foxinfested islands. To do this, we compared: (1) the nutrient status of plants and soils, and (2) the stable isotopic signature of nitrogen in soils and plants on foxfree and fox-infested islands. We predicted that soils and plants on fox-free islands would be nutrient enriched and that $\delta^{15} \mathrm{~N}$ values would be elevated, indicative of nutrients coming from higher trophic levels (i.e., marine sources; Dawson et al. 2002, Schindler and Lubetkin 2004), while plants and soils on foxinfested islands would be nutrient impoverished and have $\delta^{15} \mathrm{~N}$ signatures more indicative of internal island derivation via nitrogen fixation within those islands. We also sampled tissues from slugs, spiders, flies, and passerine bird droppings on fox-free and fox-infested islands to determine whether nutrient subsidies brought in by seabirds propagated upward and were reflected in enhanced $\delta^{15} \mathrm{~N}$ values in consumer tissue. Second, to determine the effects of soil nutrient differences on the overall vegetation characteristics of fox-free vs. fox-infested islands we compared: (1) graminoid, forb, and dwarf-shrub biomass and (2) plant community composition among island types.

To make these comparisons, in August 2001-2003, we sampled virtually every fox-free island of reasonable size ( $>10$ ha) across the Aleutian archipelago where it was possible to land a skiff and climb onto the island $(n=9)$. We paired these fox-free islands with nine historically fox-infested islands, matching the two island types as closely as possible for similarity in size and geographic position across the archipelago (Fig. 1, Table 1). Although average island size between the two groups is similar (Table 1), the size distribution differed substantially. The fox-free group included the two largest islands (Buldir and Chagulak) and an array of smaller ones whereas the fox-infested islands tended to be more intermediate in size. The reasons these nine islands remained fox-free is not entirely clear. Buldir and Chagulak may have been too rugged and remote to warrant efforts by the fox farmers, and the smaller fox-free islands may have been too small to maintain viable fox populations. Beyond these factors, we are unaware of any systematic differences between the foxfree and fox-infested islands. All of the historically foxinfested islands we sampled currently contain no foxes, 


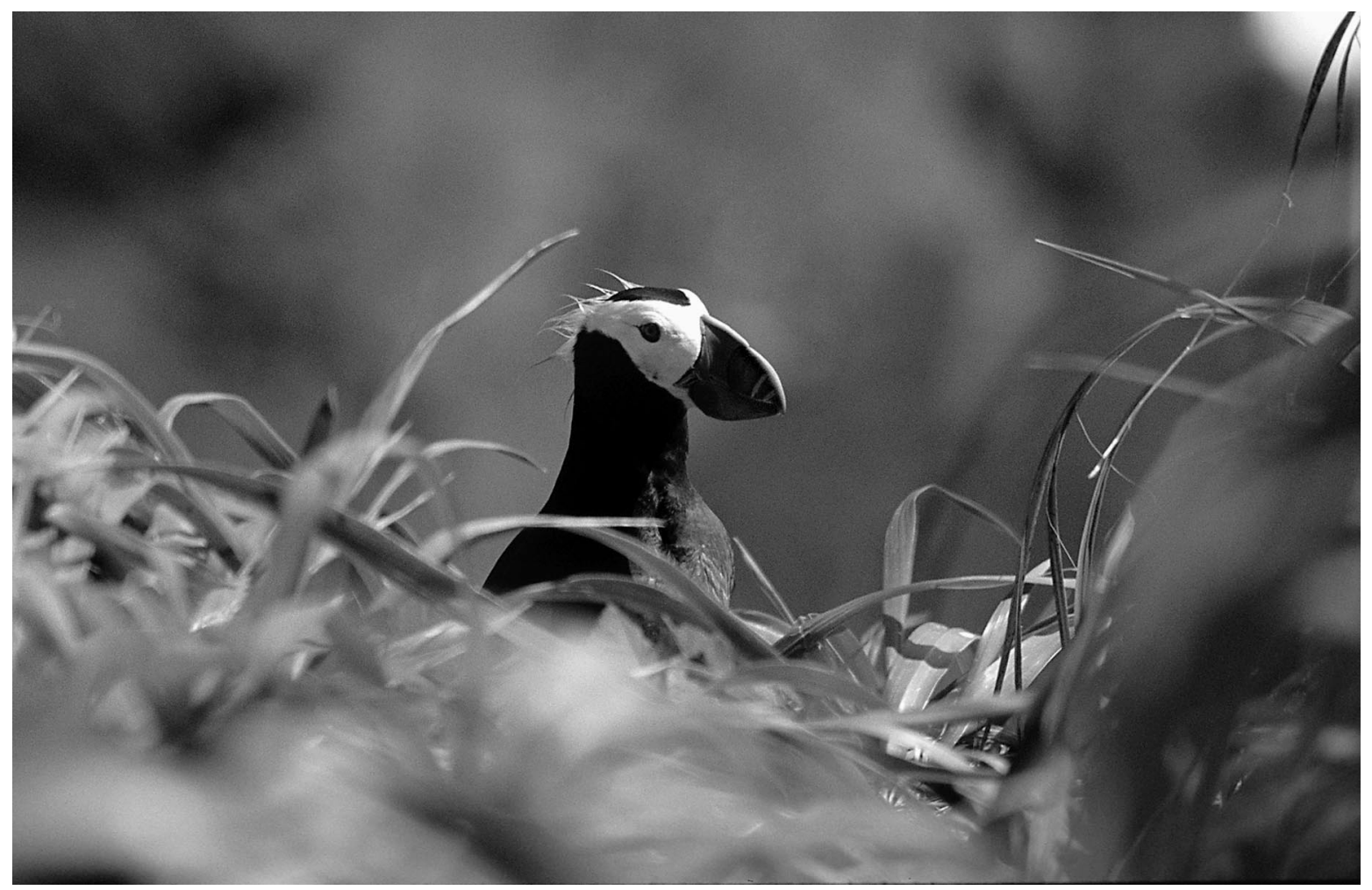

Plate 1. Tufted Puffin (Fratercula cirrhata) in beach rye (Leymus mollis). Photo credit: Stacey Buckelew.

because they have been eradicated over the last several decades by the Fish and Wildlife Service. Since a few seabirds are starting to return to some of these islands, our estimates of the effects of introduced foxes on islands throughout the Aleutian chain are likely conservative. We only sampled islands that had no history of rat introductions so as not to confound rat and fox effects.

In August 2001, we conducted preliminary sampling on six islands: Buldir, Chagulak (fox-free); and Davidof, Kasatochi, Khvastof, and Nizki (fox-infested). Details of this sampling are given in Appendix A. In early August 2002 and 2003, we conducted more comprehensive sampling on all of the aforementioned islands (except Chagulak), and on an additional set of islands (Fig. 1, Table 1). The broad goal of our 20022003 sampling effort was to obtain a representative characterization of whole-island ecosystems. Thus on each island (except Buldir), we overlaid a 12-32 point sampling grid (depending on island size) that entirely covered an electronic image of the island and used the grid points to define sample locations. For those islands that were sampled in 2001, grid points did not overlap with previously sampled points along transects. Grid points were equally spaced across each island, but the distance between grid points varied among the islands depending on island size. If a particular grid point was inaccessible (i.e., it was located on a cliff face), we sampled at the nearest accessible location. We were forced to use a somewhat different sampling approach for Buldir Island because it is so large and precipitous that grid points would have been too difficult and timeconsuming to access. Here we sampled a series of predetermined points arrayed off a trail that bisects the island.

The within-plot sampling was also modified from the 2001 protocol (Appendix A) based on analyses of the 2001 data and sampling effort. At each grid point on every island we established a $30 \times 30 \mathrm{~m}\left(900 \mathrm{~m}^{2}\right)$ plot oriented with the baseline parallel to shore. Within this plot we estimated percent cover of graminoids (grasses and sedges) vs. all non-graminoid vegetation, assigning cover by Daubenmire cover class (Mueller-Dombois and Ellenberg 1974). We also recorded the identity of the dominant species in each $30 \times 30 \mathrm{~m}$ plot, where dominance was defined as $>50 \%$ cover. Along a predetermined side of the $30 \times 30 \mathrm{~m}$ plot we placed three $1-\mathrm{m}^{2}$ subplots at 0,15 , and $30 \mathrm{~m}$ intervals. Within each subplot we also identified the dominant plants (dominance defined previously) and recorded all vascular plant species present. We also took digital photos of each subplot to assess plant cover (as described in Appendix A). Within a $20 \times 20 \mathrm{~cm}$ quadrat placed in a corner of the first $1-\mathrm{m}^{2}$ subplot (located at the $0-\mathrm{m}$ interval) we sampled aboveground biomass of all vascular plants by clipping vegetation to ground level (making sure to only harvest present year's growth). Clipped vegetation was sorted into graminoids, forbs, 
and dwarf shrubs/club mosses, and bagged separately. To simplify the time-consuming task of sorting in the field, we ignored lichens and bryophytes. In the remaining two subplots (located at the 15 and $30 \mathrm{~m}$ intervals), we harvested only graminoids from within a $20 \times 20 \mathrm{~cm}$ quadrat placed in the lower corner of each subplot. Bagged vegetation was dried in the laboratory to a constant mass and weighed. At the subplot intervals located at 0 and $30 \mathrm{~m}$ we also obtained two soil samples from 5 to $10 \mathrm{~cm}$ beneath the soil surface. Samples collected at different positions within each subplot were pooled, bagged, and processed as in 2001 and analyzed for total nitrogen and extractable (Bray) phosphorus at the University of California, Davis, DANR analytical laboratory. An aliquot of soil was dried, ground, and sent to the Colorado Plateau Stable Isotope Laboratory, Northern Arizona University (Flagstaff. Arizona) for determination of $\delta^{15} \mathrm{~N}$ (as well as $\% \mathrm{~N}$ ). Analyses were conducted using an elemental analyzer (model NA2500, Carlo Erba, Milan, Italy) coupled to a Finnigan Delta Plus isotopic ratio mass spectrometer (Thermo Electron Corporation, Waltham, Massachusetts).

Finally, within each $30 \times 30 \mathrm{~m}$ plot we haphazardly collected multiple samples of two widespread and common plants, the grass Leymus mollis and the forb Achillea borealis, for $\delta^{15} \mathrm{~N}$ analysis. If $L$. mollis was not present, we sampled the most abundant graminoid (usually Calamagrostis nutkanensis but on rare occasions Carex macrochaeta or Festuca rubra). Some sites were so graminoid-dominated that we could not find Achillea within the $30 \times 30 \mathrm{~m}$ plots.

In addition to sampling soil and plants, we also haphazardly collected at least five individuals from a diverse group of terrestrial consumers at each island, including a mollusk (Deroceras leave, collected on all islands except Chagulak, Gibson, Kohl, Kasatochi, Davidof, and Tagadak where we could not find specimens); arachinid (Cybaeus reticulates, collected on all islands except Chagulak and Tagadak); dipteran (Scathophaga impudicum, collected on all islands except Chagulak and Tagadak); and droppings from passerine birds (Lapland longspurs, Calcarius lapponicus, and song sparrows, Melospiza melodia, collected at all islands except Chagulak, Tagadak, and Vsevidof). These species often were difficult to find, so they could not be sampled at the same spatially explicit grid points where we sampled vegetation. By analyzing $\delta^{15} \mathrm{~N}$ values in these samples we could determine the degree to which nitrogen-based nutrients utilized by these organisms were marine-derived. Plant, animal, and dropping samples were dried, ground, and sent to the Stable Isotope Laboratory, Northern Arizona University for analysis of $\delta^{15} \mathrm{~N}$ values.

\section{Island sampling analyses}

We considered the presence or absence of foxes as experimental treatments, and islands with a similar his- tory of fox introduction (fox-infested islands) or lack thereof (fox-free islands) as treatment replicates. To assess differences in total soil phosphorus (square-root transformed) and nitrogen (square-root transformed); plant leaf nitrogen, dominance, cover (arcsine squareroot transformed) and biomass; and $\delta^{15} \mathrm{~N}$ in soils and plants, we pooled data collected across all years and performed separate nested ANOVAs on these response variables with island identity nested within island type (fox-free or fox-infested). These and other analyses were performed with SYSTAT (2000). Island identity was treated as a random factor and island type was treated as a fixed factor. Thus, the denominator of the $F$ test for differences between island types was the mean square error due to island identity. For some response variables (total soil phosphorus; soil, grass, and forb $\delta^{15} \mathrm{~N}$ ), variances around the island identity means were not homogeneous among islands, even after transforming the data. As such, the statistical test for differences among islands within island type may be suspect. Variances around the grand means of island types were always homogeneous. We analyzed stable isotopic signatures of grasses and forbs separately since plants of different functional type can have divergent isotopic signatures (Nadelhoffer et al. 1996). We used nested ANOVA (identical to that described previously) to compare how the relative abundance of plant functional groups varied by island type. In this analysis, the percentage of total plant biomass that was composed of graminoids (arcsine transformed) was the response variable. Differences in plant biomass between island types are not necessarily an indication of differences in growth or production since samples lacking particular plant types (i.e., graminoids, forbs, dwarf shrubs) received a zero value.

The strength of subsidies supplied to islands might vary in several ways that are a function of island size. Within islands, distance-from-shore may influence the magnitude of subsidies either because seabird vectored nutrients might decline toward the interior of large islands, or because wind-borne vectoring of nutrients from sea to land on fox-infested islands might decline with distance from shore. If either of these scenarios were true, this could be a potential source of bias in our data since fox-free islands were generally smaller than fox-infested islands (Table 1), and these smaller islands had more sampling points close to shore (due to the fact that our plots were arrayed systematically across each island). That is, potentially enriched sites that were close to shore could be overrepresented on smaller fox-free islands or underrepresented on larger fox-infested islands. In addition to these distance-fromshore effects within islands, among islands smaller islands with larger perimeter-to-area ratios may provide a larger "target" for the transport of wind-blown nutrients from ocean to land (Polis and Hurd 1996) and also provide relatively more habitat close to shore that may be preferred and more heavily utilized by seabirds. 
To examine these spatial effects, to tease them apart from fox presence/absence effects, and to compare the strength of spatial vs. fox effects, we performed the following analyses. First, we assessed how subsidies within islands varied as a function of distance-fromshore by performing separate ANCOVAs for fox-free and fox-infested islands, testing the effects of distancefrom-shore (log-transformed covariate) and island identity (used as a blocking factor) on soil, grass, and forb $\delta^{15} \mathrm{~N}$ values and total graminoid biomass (squareroot transformed). Second, we compared $\delta^{15} \mathrm{~N}$ values in soil, forb, and grass samples between fox-free and fox-infested islands, only using samples that occurred within two "bins," those from 0 to $99 \mathrm{~m}$ from shore and those from 100 to $199 \mathrm{~m}$. Because of their relatively close proximity to shore, data from such plots were available from all the islands we sampled, regardless of their size. We used a two-way ANOVA, testing for effects of bin, island type, and their interaction. Third, to further tease apart the effects of island size from those of fox presence/absence we performed an ANCOVA on mean island-wide $\delta^{15} \mathrm{~N}$ for soils and grasses, with island type as a discrete factor and island perimeter-to-area ratio as a covariate. If island size effects predominate, then after accounting for island size one would expect island type to be nonsignificant. Finally, we compared the scalar metrics from the vegetation and soil analyses (soil phosphorus, soil $\delta^{15} \mathrm{~N}$, grass $\delta^{15} \mathrm{~N}$, forb $\delta^{15} \mathrm{~N}$, grass $\% \mathrm{~N}$, and grass biomass) between fox-free and fox-infested islands, only using data from the subset of plots that occurred within $100 \mathrm{~m}$ of the coast. This provides an extremely conservative test for island type effects, because close-to-shore samples are the least likely regions of islands to show a fox presence/absence effect. To make these comparisons, in the PROC GLM module within SAS (2001) we performed an ANCOVA with Type I sum of squares, using the following model: response variable $=$ island area $(\log$ transformed) + island type (fox-infested or fox-free) + island identity nested within island type + error. Island identity nested within island type was a random factor, island type was a fixed factor, and island perimeter-to-area ratio was used as a covariate. We used Type I rather than Type III sum of squares because islands had unique sizes, and there were insufficient degrees of freedom to simultaneously use island size and island identity nested within island type within a Type III sum of squares model.

To infer how subsidies might directly influence graminoid production and extractable soil $\mathrm{P}$, we performed two separate regressions. For the first, we regressed grass $\delta^{15} \mathrm{~N}$ values (from samples collected within each $30 \times 30 \mathrm{~m}$ plot) vs. grass biomass (from samples collected in the first $1-\mathrm{m}^{2}$ subplot in each $30 \times 30 \mathrm{~m}$ plot, square-root transformed) on fox-free and fox-infested islands separately. For the second, we pooled data across all islands (both island types combined) and regressed soil $\delta^{15} \mathrm{~N}$ values vs. extractable soil $\mathrm{P}$ values.
To examine graminoid cover differences between island types, we calculated mean Daubenmire cover scores for graminoid and non-graminoid vegetation for each island and then used a Kolmogorov-Smirnov test to compare the distributions of cover class scores by island type. We compared the degree of graminoid dominance between fox-infested and fox-free islands by calculating on each island the percentage of $30 \times$ $30 \mathrm{~m}$ plots in which graminoids were the dominant plant form and then comparing these values (arcsine square-root transformed) by island type (one-way ANOVA). We similarly examined the importance of L. mollis, specifically, by calculating the percentage of plots in which L. mollis was the dominant species by island and comparing these values (arcsine square-root transformed) by island type (one-way ANOVA). We determined the relationship between $\delta^{15} \mathrm{~N}$ values in grass samples and grass biomass on fox-free islands by regressing these two variables against each other, with grass biomass square-root transformed. To assess how mean species richness $\left(\mathrm{m}^{-2}\right)$ varied by island type we performed an ANCOVA (on mean island-wide species richness values) with island area (log-transformed) as a covariate. Finally, in order to examine how plant communities differed between fox-free and fox-infested islands we performed a conditional canonical correspondence analysis (CCA) on plant species presenceabsence data obtained from the first $1-\mathrm{m}^{2}$ subplot within each $30 \times 30 \mathrm{~m}$ plot. The conditional CCA first partitions out the effects of distance-from-shore from the overall ordination and then tests whether communities differ between fox-free and fox-infested islands. This analysis was conducted using the program $\mathrm{R}$ using the Vegan package, version 1.6-9 (J. Oksanen, R. Kindt, and B. O'Hara, unpublished program package).

\section{Nutrient amendment experiments}

We initiated three different fertilization experiments on Adak Island (a very large, fox-infested island in the middle of the Aleutian chain) to: (1) determine if, in the absence of seabirds (and their nutrient inputs), plant productivity was nutrient limited, (2) examine whether experimental nutrient addition could shift plant productivity and composition toward what we commonly observed on fox-free islands, and (3) determine how disturbance (commonly created by seabirds excavating nesting burrows on fox-free islands) interacted with nutrient addition to influence plant composition and productivity. These experiments could only be conducted on fox-infested Adak Island (rather than on Adak and a paired fox-free island, which would have been more ideal) because it was logistically impossible to visit isolated fox-free islands early in the season (mid-May) when fertilizer was added to plots.

The first experiment was conducted by establishing six experimental blocks at each of two sites in upland meadow habitat. This habitat was typical of meadow sites on many of the small fox-infested islands and was 
composed of a Carex spp./Empetrum nigrum matrix interspersed with mosses, lichens, and forbs. Each block contained three $3 \times 3 \mathrm{~m}$ plots, with blocks separated by $5 \mathrm{~m}$ and plots separated by $3 \mathrm{~m}$. Each of the three plots within a block was randomly assigned one of the following treatments: (1) control, (2) low nutrient amendment (12 g N/m $\mathrm{m}^{2}$ and $\left.2 \mathrm{~g} \mathrm{P} / \mathrm{m}^{2}\right)$, and (3) high nutrient amendment $\left(36 \mathrm{~g} \mathrm{~N} / \mathrm{m}^{2}, 6 \mathrm{~g} \mathrm{P} / \mathrm{m}^{2}\right)$. Low and high nutrient treatments were designed to mimic both amounts of nitrogen and phosphorus and the ratio of nitrogen to phosphorus deposited on islands with moderate and high levels of seabirds (Furness 1991). We mixed Treble superphosphate $(0-45-0)$ and 6-8 week slow release sulphur polymer coated 42-0-0 urea (brand name, "Trikote," Pursell Technologies, Sylacauga, Alabama, USA) to attain the desired concentrations of nutrients. We added nutrients to plots (and an area that extended $0.5 \mathrm{~m}$ beyond the perimeter of each plot) in mid-May 2002-2004, just as the vegetation was starting to green up. We sampled the plots in early August in 2002-2004, estimating the percent cover of graminoids, forbs, and dwarf shrubs and recording species presence/absence in a permanently marked $1-\mathrm{m}^{2}$ quadrat in the center of each plot. We sampled all aboveground plant biomass in a $20 \times 20 \mathrm{~cm}$ quadrat. The edge of this quadrat was placed along a randomly selected position parallel and directly adjacent to the side of each plot. These $20 \times 20 \mathrm{~cm}$ quadrats were placed at different predetermined locations within each plot every year so that the prior year's harvest did not affect results. In 2001, we measured biomass in each plot but we did not sort harvested vegetation. In 20022004 we sorted and bagged biomass separately by: (1) graminoids, (2) forbs, (3) dwarf shrubs, and (4) lichens, mosses, and lycopodium. Biomass samples were dried to a constant mass and weighed in the laboratory.

Since there was often substantially greater L. mollis dominance on fox-free vs. fox-infested islands we established a second fertilization experiment to examine whether L. mollis cover and biomass was particularly sensitive to nutrient addition on these islands. L. mollis is a robust clonal grass that can grow in lush waisthigh stands on fox-free islands (see Plate 1). The design of this experiment and fertilization protocols were identical to the previous one, except that we established experimental plots specifically in areas that contained scattered L. mollis. In August 2000, prior to the first fertilization in mid-May 2001, we estimated the cover and counted the total number of $L$. mollis ramets within each $3 \times 3 \mathrm{~m}$ plot. In addition, we counted L. mollis ramets within a permanently marked $1-\mathrm{m}^{2}$ subplot in the interior of each $3 \times 3 \mathrm{~m}$ plot. By 2004 the number of stems in the entire $3 \times 3 \mathrm{~m}$ fertilized plots had become too great to count so we only counted stems within the interior $1 \mathrm{~m}^{2}$.

Several studies have found that seabirds can alter plant productivity by burrowing and trampling (Hogg and Morton 1983, Vidal et al. 2000). Our third exper- iment was designed to determine how nutrients and physical disturbance jointly affect plant biomass and composition. We established six experimental blocks at the interface between a dense L. mollis/C. nutkanensis dominated swath and more typical dwarf shrub/ grass dominated habitat. Our objective was to determine how graminoid biomass was influenced by the interaction between fertilization and disturbance. We established six experimental blocks separated by $5 \mathrm{~m}$. Each block contained four $1 \times 3 \mathrm{~m}$ plots, each separated by $3 \mathrm{~m}$. Plots were laid out so that one-third of each plot was in a dense grass-dominated sward and two-thirds of the plot was in lower lying tundra with Carex spp. and sparse L. mollis. We randomly assigned the following four treatments to plots within blocks: (1) control, (2) disturbance only, (3) nutrient addition only, and (4) disturbance + nutrient addition. In August 2000 we initiated the disturbance treatment by cutting and peeling back soil and plants within each plot. From 2002 to 2004 we added a mix of $36 \mathrm{~g} \mathrm{~N} / \mathrm{m}^{2}$ and $6 \mathrm{~g}$ $\mathrm{P} / \mathrm{m}^{2}$ (identical to the high fertilization levels used in experiments 1 and 2 described previously) to nutrient addition plots in mid-May prior to green up. In early August 2002-2004 we sampled the biomass in these plots using the same methods described previously.

\section{Nutrient amendment experiments analyses}

We used repeated-measures ANOVA to analyze the effects of nutrient amendments on plant biomass, grass tissue nitrogen concentration, and species richness per plot (first experiment), and the number of L. mollis ramets in plots through time (second experiment). Preliminary analyses revealed that block effects were not significant so these were dropped from the analyses. Site effects were not significant so they are not reported. For the third experiment we used a two-way ANOVA to determine how disturbance and fertilization (and their interaction) influenced plant biomass at the end of the experiment.

\section{RESULTS}

\section{Soil and plant nutrients and $\delta^{15} N$ values}

The nutrient profiles of soils and plants on fox-infested islands were substantially different than those on fox-free islands. Levels of extractable phosphorus from soil on fox-infested islands were almost one-quarter those on fox-free islands (Fig. 2a; Appendix B). Although there were no significant differences in total soil nitrogen between fox-infested and fox-free islands (Fig. 2b; Appendix B), leaves of grasses (Fig. 2c) and the forb, Achillea borealis, contained substantially more nitrogen on fox-free than on fox-infested islands (Appendix B).

Increased soil and plant fertility on fox-free islands was clearly the result of nutrient subsidies delivered from sea to land by seabirds. Across all islands, extractable soil phosphorus increased as soil $\delta^{15} \mathrm{~N}$ became 

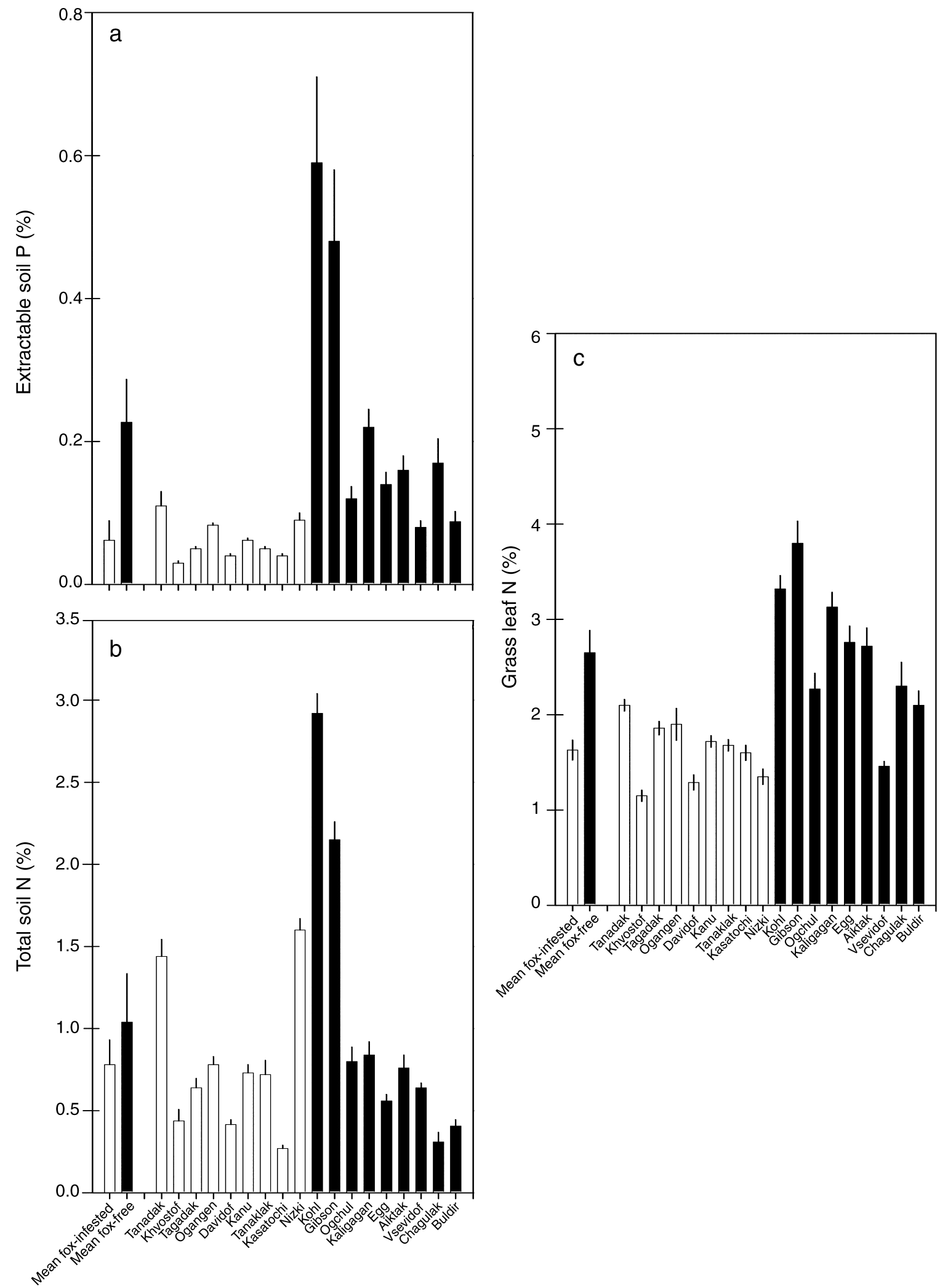

FIG. 2. (a) Extractable soil phosphorus, (b) total soil nitrogen, and (c) grass leaf tissue nitrogen (as percentage of dry mass leaf tissue; mean + SE) on fox-free (black bars) and fox-infested (open bars) islands. Within island type (i.e., fox-free or fox-infested) islands are arranged from left to right, in order of smallest to largest size. 
increasingly enriched $\left(R^{2}=0.19, P<0.0001\right)$, and $\delta^{15} \mathrm{~N}$ values in soils, grasses, and the forb, A. borealis, were all substantially higher on fox-free compared to fox-infested islands (Fig. 3a-c; Appendix B).

\section{Island size effects}

Since the fox-infested islands we sampled tended to be larger than those that were fox-free (Table 1), the average distance of all sampling plots on these larger islands was further from the coast than was the case for smaller fox-free islands. This could potentially bias island-wide estimates of $\delta^{15} \mathrm{~N}$ values of soil or plants, or in graminoid biomass, if physical vectoring (via wind) of marine subsidies compensates for the lack of seabird input on fox-infested islands and enriched close-to-shore sites are undersampled on fox-infested islands. To evaluate whether this could have been the case, within islands we examined how $\delta^{15} \mathrm{~N}$ values in soils and plants and graminoid biomass varied as a function of distance from shore. On fox-infested islands, $\delta^{15} \mathrm{~N}$ values in soil and grasses declined with distance inland (Fig. 4a, b; ANCOVA, $F_{1,238}=9.1, P$ $<0.0003$ and $F_{1,212}=18.4, P<0.0001$ for soils and grasses, respectively) as did total graminoid biomass (Fig. 4c; ANCOVA, $F_{1,194}=57.9, P<0.0001$ ). However, the distance-from-shore decline in $\delta^{15} \mathrm{~N}$ values and graminoid biomass on fox-infested islands occurred over low, unenriched $\delta^{15} \mathrm{~N}$ values (Fig. 4). Thus, with the possible exception of extremely close-to-shore samples (those between 0 and $49 \mathrm{~m}$ ), in general there is little evidence that fox-free islands receive substantial wind-borne marine subsidies.

While $\delta^{15} \mathrm{~N}$ values of soils and grass on fox-free islands also declined as a function of distance from shore (ANCOVA, $F_{1,198}=40.3, P<0.0001$ and $F_{1,178}=$ 33.5, $P<0.0001$ for soil and grass, respectively), in contrast to fox-infested islands, mean $\delta^{15} \mathrm{~N}$ values on fox-free islands remained enriched even at distances far inland (Fig. 4a, b). Furthermore, graminoid biomass was uniformly high and did not decline significantly with distance from shore (ANCOVA, $F_{1,189}=2.4, P$ $=0.12$ ).

To test whether differences between fox-free and fox-infested islands existed after controlling for these distance-from-shore effects, we compared $\delta^{15} \mathrm{~N}$ values in soil, forb, and grass samples between island types for the subset of plots that occurred in two strata (the shoreline to $99 \mathrm{~m}$ inland, and 100-199 $\mathrm{m}$ inland). These areas are the least likely to be different between island types if physical vectoring (via wind) of marine subsidies compensates for the lack of seabird input on foxinfested islands. Yet, even among close-to-shore samples we found significant differences among island types in soil $\delta^{15} \mathrm{~N}\left(F_{1,30}=47.9, P<0.0001\right)$, grass $\delta^{15} \mathrm{~N}\left(F_{1,29}=59.0, P<0.0001\right)$, and forb $\delta^{15} \mathrm{~N}\left(F_{1,23}=\right.$ 26.5, $P<0.0001)$ as well as grass biomass $\left(F_{1,26}=\right.$ 25.2, $P<0.0001)$. There were also significant differences between the 0-99 $\mathrm{m}$ and 100-199 $\mathrm{m}$ sampling "bins" in $\delta^{15} \mathrm{~N}$ of soil $\left(F_{1,30}=22.1, P<0.45\right)$ grass $\left(F_{1,29}=7.9, P<0.0009\right)$ as well as graminoid biomass $\left(F_{1,26}=18.0, P<0.0001\right)$ but not for $\delta^{15} \mathrm{~N}$ of forbs $\left(F_{1,23}=0.08, P=0.77\right)$. None of the bin by island type interactions were statistically significant $(P>0.05)$.

At the scale of entire islands, although the magnitude of marine-based nutrient subsidies varied with island perimeter-to-area ratio (ANCOVA, $F_{1,15}=33.7$, and $F_{1,15}=35.4, P<0.0001$ for $\delta^{15} \mathrm{~N}$ soil and grasses, respectively), after statistically controlling for this island size effect, mean $\delta^{15} \mathrm{~N}$ values for soils (ANCOVA, $\left.F_{1,15}=20.1, P<0.0001\right)$ and grass (ANCOVA, $F_{1,15}$ $=29.0, P<0.0001)$ were still significantly more enriched on fox-free islands vs. fox-infested islands. Because the significant relationship between island perimeter-to-area ratio and ${ }^{15} \mathrm{~N}$ of soil and grass for foxinfested islands may have been driven by one point (Tanadak; Fig. 5), we performed an identical, but more conservative analysis. This involved comparing islandwide means of $\delta^{15} \mathrm{~N}$ in soil and grass among the subset of fox-free islands and fox-infested islands that had similar perimeter-to-area ratios (between 10 and 55; Fig. 5). Constraining the analysis to include only these relatively large islands of similar perimeter-to-area ratio reduces the comparison to four fox-infested and eight fox-free islands. Even with the reduced statistical power of this more limited analysis, significant differences remain between fox-free and fox-infested islands in island-wide mean $\delta^{15} \mathrm{~N}$ values for soil $\left(F_{1,10}=21.6\right.$, $P<0.001)$ and grass $\left(F_{1,10}=34.0, P<0.0001\right)$. With this restricted group of islands, there was no effect of island perimeter-to-area ratio on $\delta^{15} \mathrm{~N}$ values for soil $\left(F_{1,10}=1.4, P=0.26\right)$ and grass $\left(F_{1,10}=2.3, P=\right.$ $0.16)$.

Finally, to ensure that island types did not differ intrinsically due to some unknown attribute related to island size, we again only analyzed data taken within points close to shore $(0-100 \mathrm{~m})$, examining the effects of island size (as a covariate) and type (fox-free vs. fox-infested) on $\delta^{15} \mathrm{~N}$ values for soils, grasses and forbs (i.e., A. borealis) and on soil phosphorus and graminoid biomass. These analyses allowed us to statistically compare the strength of any intrinsic island size effect that might be unrelated to distance-from-shore to that of fox presence/absence. The results from this analysis indicated that island type effects were overwhelmingly significant, even though island size effects were also significant in most cases (Appendix C). Thus, while island-size effects related to distance from shore and island perimeter-to-area ratio are clearly important, differences in subsidies delivered within and among foxfree and fox-infested islands are not simply a consequence of fox-free islands being generally smaller than fox-infested islands.

\section{Plant community composition}

Differences between fox-infested and fox-free islands in the nutrient status of soils and plants and the 

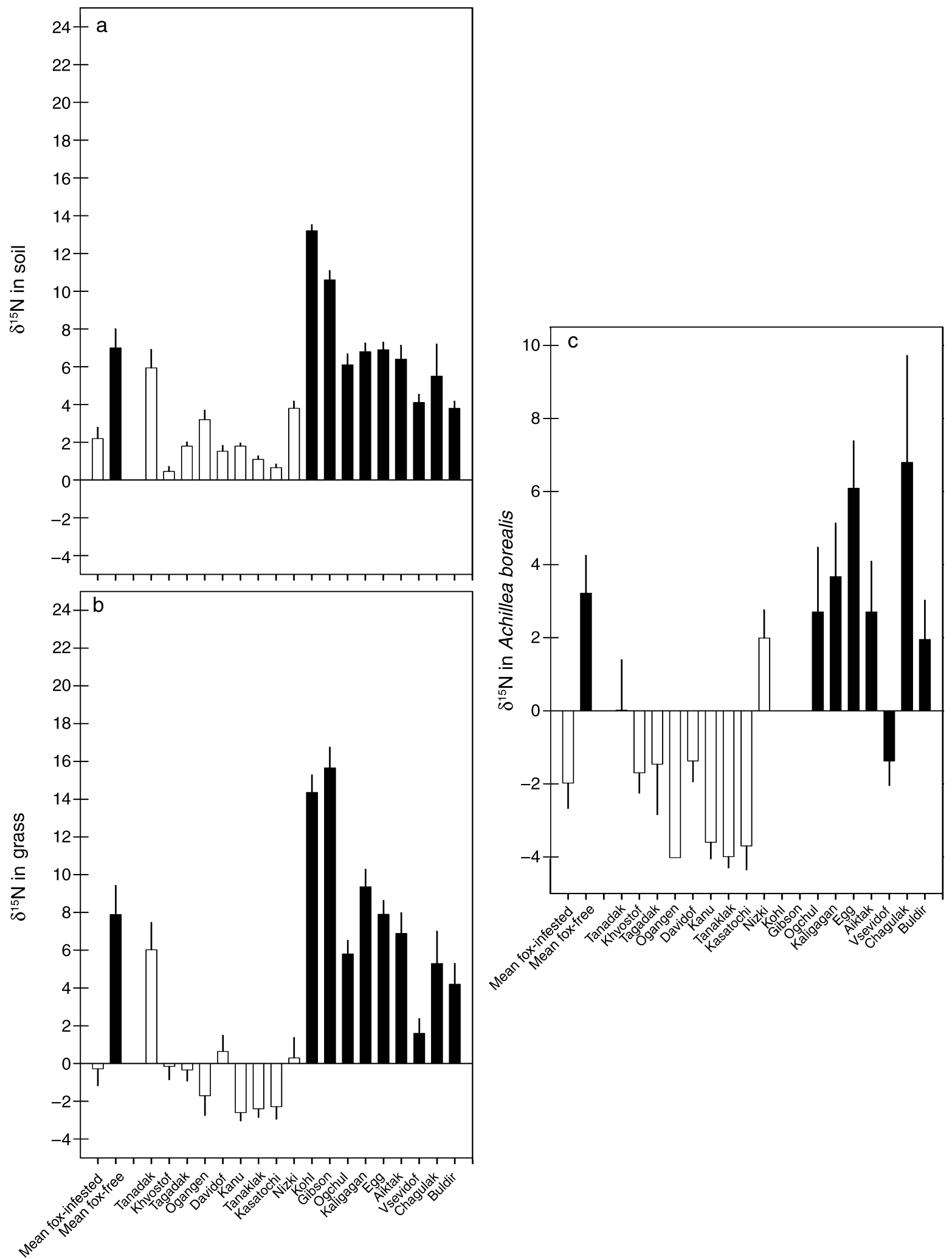

FIG. 3. Content of $\delta^{15} \mathrm{~N}$ (mean $+\mathrm{SE}$ ) in (a) soil and (b) grass, and (c) Achillea borealis on fox-free (black bars) and foxinfested (open bars) islands. Within island type (i.e., fox-free or fox-infested), islands are arranged from left to right, in order of smallest to largest size. 


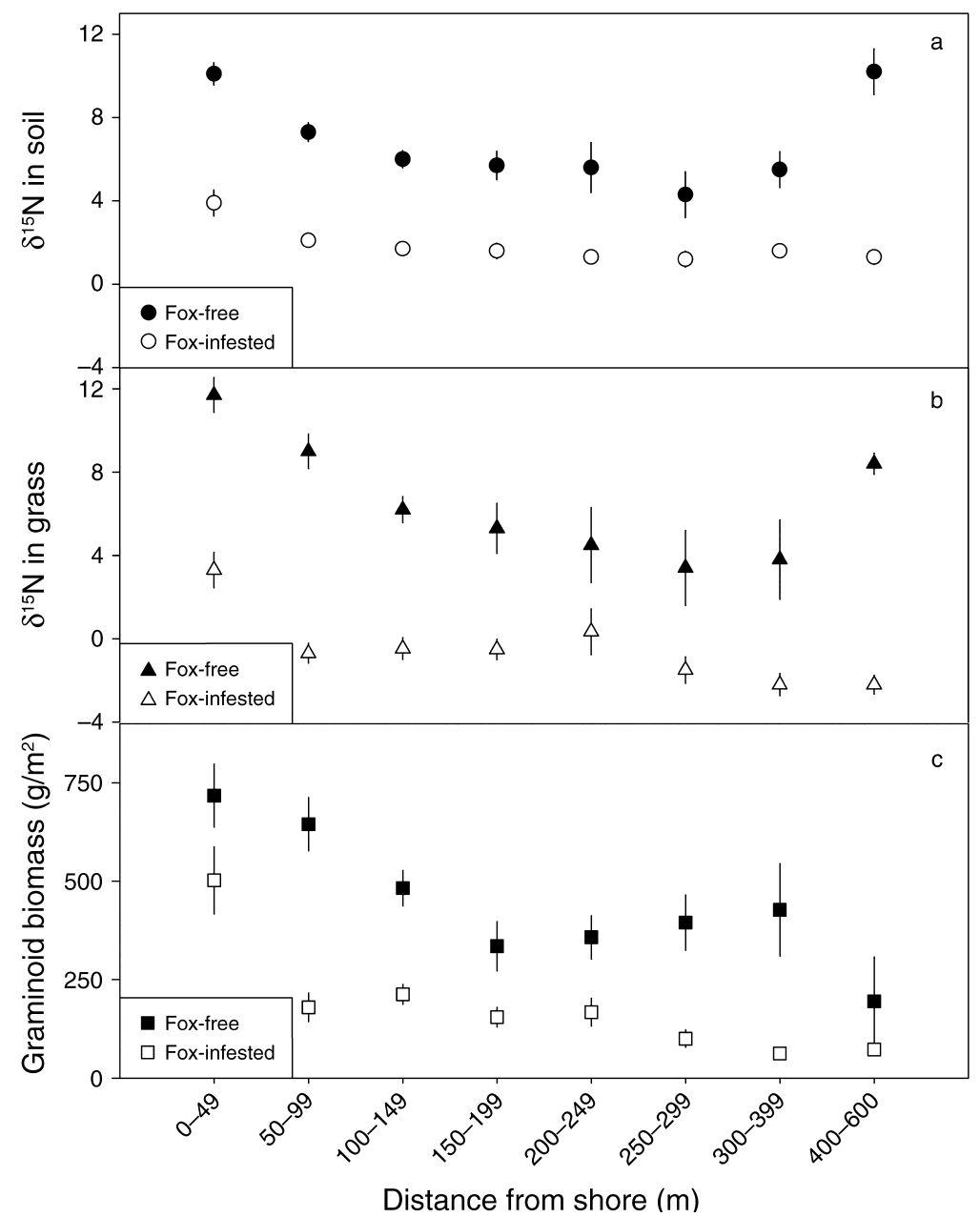

FIG. 4. Relationship between distance from shore and $\delta^{15} \mathrm{~N}$ values (mean $\pm \mathrm{SE}$ ) of (a) soil and (b) grass, and (c) dry graminoid biomass (mean $\pm \mathrm{SE}$ ). Black symbols represent fox-free islands; open symbols represent fox-infested islands. Statistical analyses testing for effects of distance from shore (see Results: Island size effects) were performed on unbinned data.

source of those nutrients coincided with large differences in plant communities between these island types. Plant communities on fox-free islands were densely covered with lush, highly productive grasses (often monodominant stands of $L$. mollis or mixed L. mollis/ Calamagrostris spp. meadows) and sedges (Carex spp.) whereas communities on fox-infested islands typically had sparser graminoid cover and greater cover of dwarf-shrubs, forbs, mosses, and lichens. These differences in community composition between island types are reflected in the following comparisons: first, graminoids were the dominant plant types in $84 \%$ of the $30 \times 30 \mathrm{~m}$ plots on fox-free islands vs. only $60 \%$ on fox-infested islands and the distribution of cover class scores was different between island types (Kolmogorov-Smirnov test, $d=0.87, P<0.0001)$. An average of $57 \%$ of plots on fox-free islands had $L$. mollis as the dominant grass, whereas this was true in only $17 \%$ of the plots on fox-infested islands (nested
ANOVA, $\left.F_{1,15}=10.5, P<0.007\right)$. In contrast, the 30 $\times 30 \mathrm{~m}$ plots on fox-infested islands had greater cover of non-graminoid plants (i.e., mostly dwarf shrubs and forbs) than did plots on fox-free islands (nested ANOVA, $\left.F_{1,15}=10.09, P<0.007\right)$. Within smaller $1-\mathrm{m}^{2}$ subplots, average cover of L. mollis (as calculated from digital photos) was also greater on fox-free islands compared to fox-infested islands (Fig. 6a; nested ANOVA, $\left.F_{1,16}=24.9, P<0.0001\right)$ and average forb (excluding umbels that were often intermixed with dense grass stands on fox-free islands) plus dwarf-shrub cover was greater on fox-infested islands $(30 \%)$ vs. foxfree islands $\left(6 \%\right.$; nested ANOVA, $F_{1,16}=16.4, P<$ $0.001)$.

Second, graminoid biomass was substantially greater on fox-free $\left(\right.$ mean $\left.=580 \mathrm{~g} / \mathrm{m}^{2}\right)$ than on fox-infested $\left(\right.$ mean $\left.=197.5 \mathrm{~g} / \mathrm{m}^{2}\right)$ islands (Fig. 6b), and total plant biomass was marginally significantly greater on foxfree vs. fox-infested islands $\left(F_{1,15}=3.3, P=0.09\right)$. 


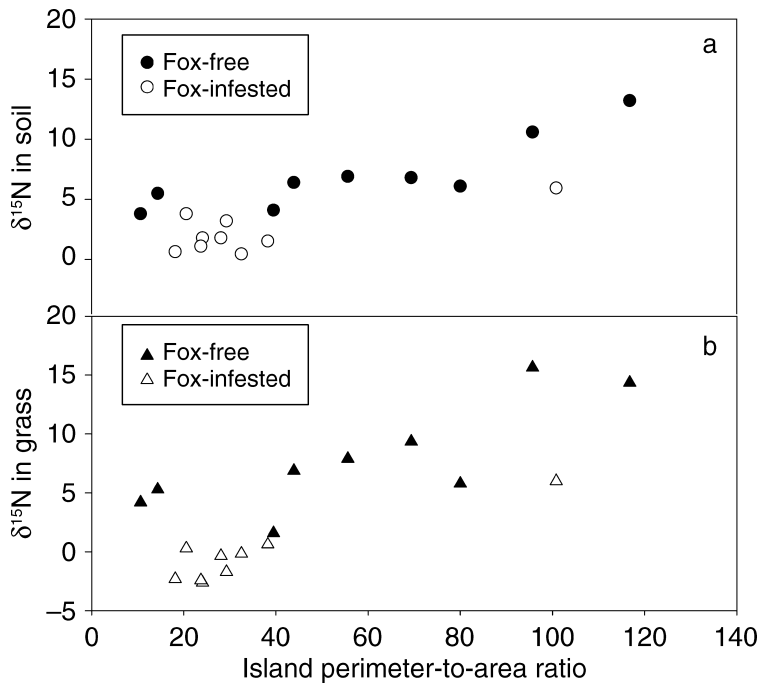

FIG. 5. Relationship between island perimeter-to-area ratio and mean island-wide $\delta^{15} \mathrm{~N}$ values of (a) soil and (b) grass. Black symbols represent fox-free islands; open symbols represent fox-infested islands.

Part of the difference in graminoid biomass between island types was related to island perimeter-to-area ratio; islands with greater perimeter-to-area ratios supported greater graminoid biomass than did larger islands (ANCOVA, $F_{1,14}=57.2, P<0.0001$ ). Yet, even after controlling for island perimeter-to-area effects there were significant differences in graminoid biomass due to the presence or absence of foxes (ANCOVA, $\left.F_{1,14}=6.9, P<0.02\right)$. Graminoids composed an average of $81 \%$ of the total plant biomass on fox-free islands, but only $46 \%$ of the total plant biomass on foxinfested islands, a significant difference $\left(F_{1,15}=14.6\right.$, $P<0.003)$. Graminoid biomass on fox-free islands increased as $\delta^{15} \mathrm{~N}$ values in grass increased (Fig. 6c; $R^{2}$ $\left.=0.15, F_{1,184}=34.2, P<0.0001\right)$; thus marine inputs of nutrients on fox-free islands likely fueled greater graminoid abundance. On fox-infested islands, dwarfshrub biomass (mean biomass, $122.5 \mathrm{~g} / \mathrm{m}^{2}$ ) was significantly greater than on fox-free islands (mean biomass, $12 \mathrm{~g} / \mathrm{m}^{2}$; Appendix B), but there was no difference between island types in forb biomass (Appendix B).

Finally, at the local $\left(1 \mathrm{~m}^{2}\right)$ scale, plant species richness differed between fox-free and fox-infested islands. After controlling for the significant effect of island size on the mean number of vascular plant species per square meter (ANCOVA, $F_{1,14}=14.7, P<0.003$ ), mean species richness per subplot was marginally higher on fox-infested vs. fox-free islands (ANCOVA, island type, $\left.F_{1,14}=4.2, P<0.06\right)$. Increased graminoid dominance on fox-free islands likely caused reductions in plant species richness on these islands. Across all subplots on all islands, there was a significant negative relationship between graminoid biomass and plant species richness $\left(R^{2}=0.12, F_{1,225}=166.0, P<0.001\right)$.
As well, at this small $\left(1 \mathrm{~m}^{2}\right)$ scale, we found significant differences between island types in plant community composition, even after distance-from-shore effects were removed (conditional CCA; $\chi^{2}=0.18, F_{1,124}=$ $3.3, P<0.005)$.

Although plant composition varied among island types at small spatial scales, there was no significant difference between island types in the number of species sampled per island (ANCOVA, $F_{1,14}=2.2, P=$ $0.16)$, after island size effects were accounted for $\left(F_{1,14}\right.$ $=14.6, P<0.003)$. Thus, at the local $\left(1 \mathrm{~m}^{2}\right)$ scale, shifts in dominance of particular plant types appeared to coincide with changes in species richness.

\section{Higher trophic levels}

By thwarting nutrient deposition by seabirds, foxes cut off a source of nutrients for both plants and for animals at higher trophic levels on fox-infested islands. $\delta^{15} \mathrm{~N}$ values in slugs, flies, spiders, and passerine bird scat were relatively low on fox-infested islands, but universally elevated on fox-free islands (Table 2). The difference in $\delta^{15} \mathrm{~N}$ between island types was very similar across each of the four consumer groups.

\section{Fertilization experiments}

Plant communities typical of those on fox-infested islands responded significantly to nutrient additions. Grass and sedge biomass increased dramatically in fertilization plots over the period of the nutrient addition experiment but over the same time interval these measures remained largely unchanged in the control plots (Fig. 7a; Appendix D). As well, at the end of the experiment levels of nitrogen in grass from fertilized plots was significantly higher than that in grass from control plots (ANOVA, $F_{2,28}=51.1, P<0.0001$ ). Leaf tissue nitrogen in grasses harvested from plots receiving the high fertilizer treatment averaged $2.9 \%$ of dry mass, commensurate with amounts of nitrogen in leaf tissue of L. mollis harvested from fox-free islands (mean nitrogen $=2.65 \%$ of dry mass). Tissue nitrogen from grasses harvested from control plots averaged $1.4 \%$ of dry mass, similar to values obtained from L. mollis harvested from fox-infested islands, which averaged $1.6 \%$ of dry mass.

Unlike for grasses, over time, dwarf shrubs were negatively affected by nutrient additions (Appendix D) and over time, fertilization led to significant declines in species richness (Fig. 7b; Appendix D).

In our second experiment, we found that L. mollis, the dominant grass on fox-free islands, responded dramatically to nutrient addition. Over time and across both sites, L. mollis abundance increased from an average of 11 stems and/or ramets $/ \mathrm{m}^{2}$ to 43 stems and/ or ramets $/ \mathrm{m}^{2}$ in high fertilization plots compared to an increase from 8 ramets $/ \mathrm{m}^{2}$ to 10 ramets $/ \mathrm{m}^{2}$ in control plots (Fig. 7c; Appendix E). At the end of the experiment, there were significant effects of fertilization $\left(F_{2,30}=26.6, P<0.0001\right)$, site $\left(F_{1,30}=26.3, P<\right.$ 

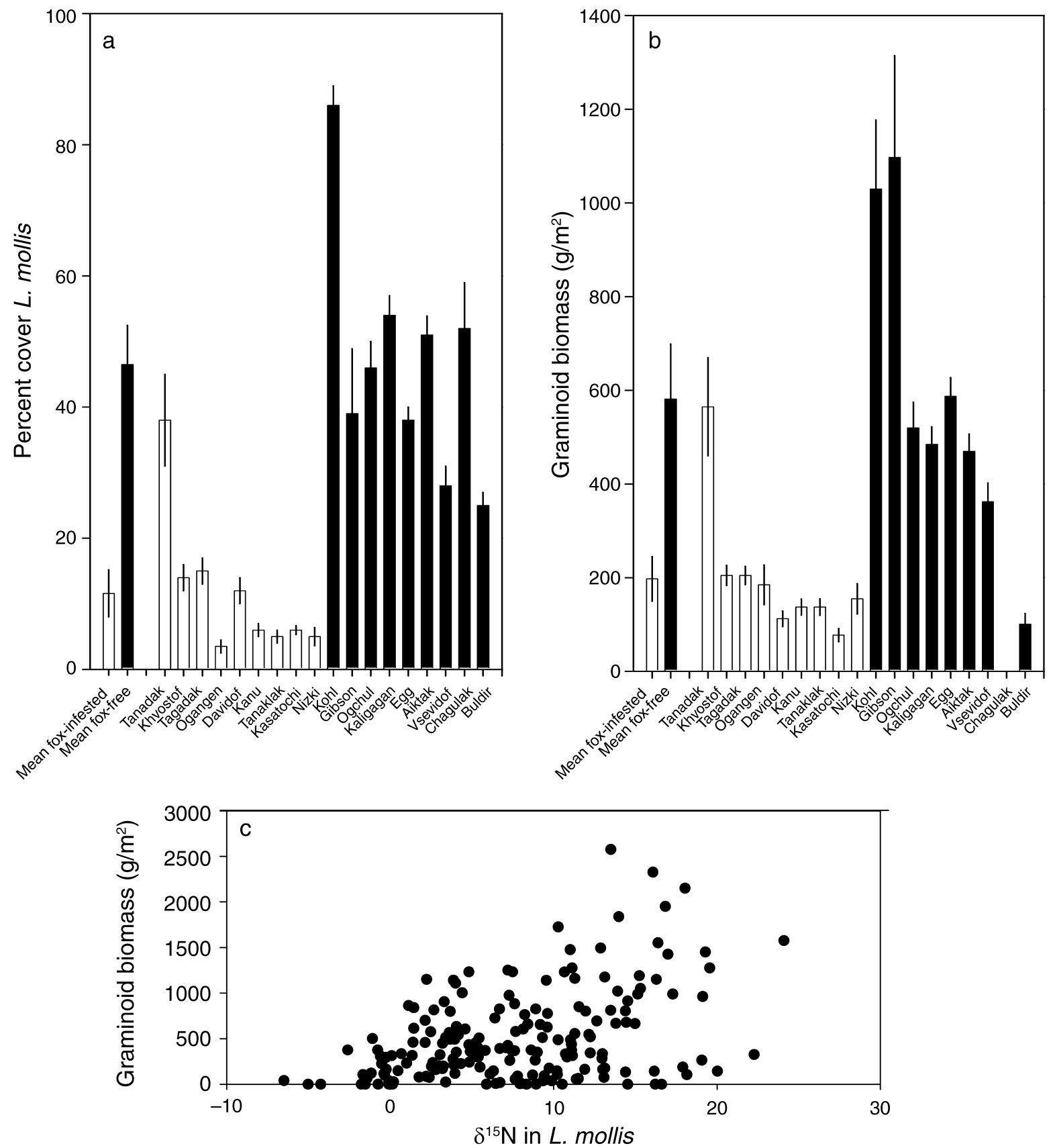

FIG. 6. (a) Percent cover of L. mollis and (b) dry graminoid biomass (mean + SE) on fox-free (black bars) and foxinfested (open bars) islands. (c) Relationship between $\delta^{15} \mathrm{~N}$ values in grass from samples collected in each $30 \times 30 \mathrm{~m}$ plot and graminoid biomass (dry mass) within a $0.2 \times 0.2 \mathrm{~m}$ subplot nested in one $1-\mathrm{m}^{2}$ subplot embedded in the $30 \times 30 \mathrm{~m}$ plot on fox-free islands.

$0.0001)$, and a fertilization $\times$ site interaction $\left(F_{2,30}=\right.$ 10.2, $P<0.0001)$.

In a third experiment to determine the interactive effects of fertilization and disturbance, fertilization generally increased graminoid biomass (two-way ANOVA, $\left.F_{1,20}=32.7, P<0.0001\right)$ as well as total plant biomass (two-way ANOVA, $F_{1,20}=4.9, P<0.04$ ). Disturbance, however, decreased total plant biomass (two-way ANOVA, $F_{1,20}=21.8, P<0.0001$ ) and in our fertilization + disturbance plots, fertilization only ameliorated the negative effects of disturbance for graminoids (two-way ANOVA, fertilization $\times$ disturbance interaction, $\left.F_{1,20}=8.7, P<0.0009\right)$. However, graminoid biomass in the disturbance + fertilization treatment (215 g dry mass $/ \mathrm{m}^{2}$ ) was still substantially lower than that in the fertilized only plots $(720 \mathrm{~g}$ dry 
TABLE 2. Mean $\delta^{15}$ values for slugs, flies, spiders, and passerine bird droppings on fox-free and fox-infested islands.

\begin{tabular}{|c|c|c|c|c|}
\hline \multirow[b]{2}{*}{ Island } & \multicolumn{4}{|c|}{$\delta^{15} \mathrm{~N}$ values } \\
\hline & Slug & Fly & Spider & Bird \\
\hline \multicolumn{5}{|c|}{ Fox-free islands } \\
\hline Buldir & 9.2 & 9.6 & 13.8 & 11.1 \\
\hline Vsevidof & 3.2 & 10.9 & 9.3 & \\
\hline Aiktak & 7.4 & 11.6 & 12.4 & 7.1 \\
\hline Egg & 8.0 & 11.7 & 15.7 & 11.8 \\
\hline Kaligagan & 6.6 & 11.6 & 12.3 & 8.9 \\
\hline Gibson & & 14.8 & 23.3 & 16.9 \\
\hline Ogchul & 13.5 & 16.5 & 11.9 & 10.4 \\
\hline Mean $\pm \mathrm{SE}$ & $8.0 \pm 1.4$ & $12.4 \pm 0.9$ & $14.1 \pm 1.7$ & $11.0 \pm 1.4$ \\
\hline \multicolumn{5}{|c|}{ Fox-infested islands } \\
\hline Nizki & 4.8 & 9.4 & 7.8 & 7.9 \\
\hline Kasatochi & & 6.8 & 4.9 & 2.5 \\
\hline Davidof & & 7.9 & 6.6 & 4.7 \\
\hline Tanaklak & 0.4 & 5.5 & & 3.3 \\
\hline Kanu & 0.5 & 7.5 & 5.5 & \\
\hline Khvostof & & 8.4 & 6.6 & 6.8 \\
\hline Tagadak & & & & 6.6 \\
\hline Tanadak & 2.1 & 8.4 & 9.8 & 9.2 \\
\hline Mean $\pm \mathrm{SE}$ & $2.0 \pm 1.0$ & $7.9 \pm 0.3$ & $6.7 \pm 0.6$ & $5.8 \pm 0.9$ \\
\hline
\end{tabular}

mass $/ \mathrm{m}^{2}$ ) and not significantly different from control plots (post hoc contrast, $P=0.57$ ). At the end of the experiment, graminoid biomass averaged $145 \mathrm{~g}$ dry $\mathrm{mass} / \mathrm{m}^{2}$ in control plots vs. $720 \mathrm{~g}$ dry mass $/ \mathrm{m}^{2}$ in fertilized only plots, and total plant biomass averaged 674 g dry mass $/ \mathrm{m}^{2}$ in control plots and $847 \mathrm{~g}$ dry mass $/ \mathrm{m}^{2}$ in fertilization only plots. Disturbance reduced total plant biomass from $674 \mathrm{~g}$ dry mass $/ \mathrm{m}^{2}$ in control plots to $55 \mathrm{~g}$ dry mass $/ \mathrm{m}^{2}$ in disturbance only plots. Total plant biomass was unaffected by a fertilization
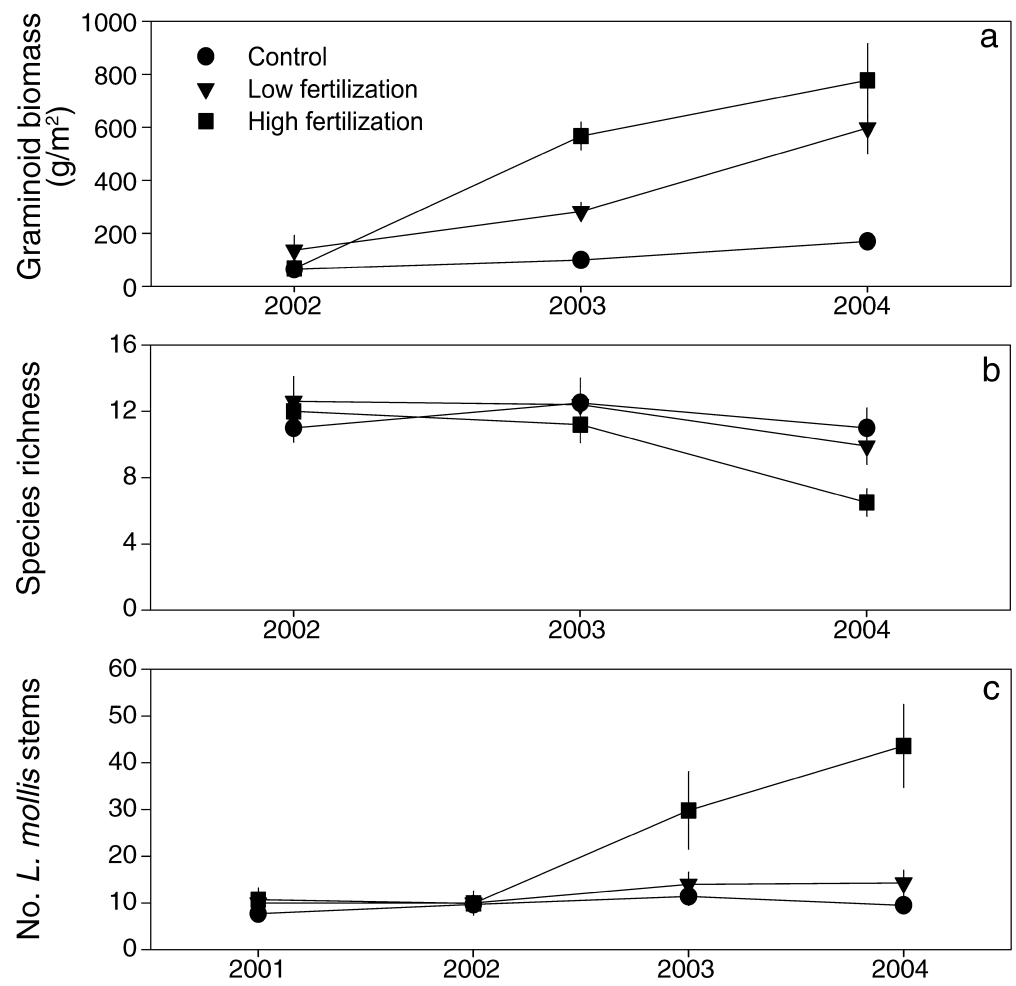

FIG. 7. (a) Dry graminoid biomass, (b) species richness, and (c) number of Leymus mollis stems and/or ramets (mean \pm $\mathrm{SE}$ ) in the central $1-\mathrm{m}^{2}$ portion of plots through time. Means in panels (a) and (b) were calculated by pooling plots across both sites; $n=12$ plots. 
by disturbance interaction $\left(F_{1,20}=0.65, P=0.3\right)$; total plant biomass in both fertilized and disturbed plots averaged $422 \mathrm{~g}$ dry mass $/ \mathrm{m}^{2}$ (compared to $674 \mathrm{~g}$ dry mass/ $\mathrm{m}^{2}$ in control plots).

\section{DISCUSSION}

While much theoretical and empirical work has focused on elucidating the conditions under which predators indirectly influence primary production by strictly trophic means (e.g., trophic cascades), our study contributes to emerging evidence indicating that predators can also influence primary production by mediating the supply of limiting nutrients (Vanni and Layne 1997, Beard et al. 2002). We have shown that a top predator, by consuming organisms that transport nutrients between ecosystems, strongly influenced plant productivity and community composition at the base of island food webs. This represents a relatively novel route by which both top-down and bottom-up forces can interact to influence the structure of food webs (Hunter and Price 1992). Although we have presented clear evidence that foxes influence the terrestrial plant community and ecosystem dynamics through one particular route, there may be other pathways by which foxes have influenced these islands. For example, the Aleutian Canada goose is potentially an important herbivore. Once-abundant Aleutian geese were driven to the brink of extinction by the introduced foxes (Byrd and Day 1986), and thus fox predation may also have influenced terrestrial plants through the more traditional top-down trophic cascade. Although the geese have recently recovered on a few islands following the removal of foxes, most islands remain devoid of geese. Foxes likely had similar though less dramatic effects on various other terrestrial bird species, and it is equally possible that these interactions influenced the structure and dynamics of the terrestrial ecosystems in unknown ways.

\section{Effects of fox introduction on seabirds and nutrient subsidies}

Across the Aleutian Islands, historical fox introductions had devastating direct effects on avifauna that used these isolated islands to breed (Dall 1874, Murie 1959, Black 1984, Bailey 1993). Considering only the islands we sampled, mean seabird abundance was much higher on fox-free vs. fox-infested islands (Table 1). Based on this difference in seabird densities between island types and metabolic and feeding rates of different seabird species, we estimate that average annual guano input is reduced from $361.9 \mathrm{~g} / \mathrm{m}^{2}$ on fox-free islands to only $5.7 \mathrm{~g} / \mathrm{m}^{2}$ on fox-infested islands (Croll et al. 2005). Since guano is rich in nitrogen and phosphorus (Hutchinson 1950), fox predation on seabirds has resulted in substantial losses in nutrient inputs to fox-infested islands.

Reductions in the magnitude of nutrient subsidies provided by seabirds on fox-infested islands corre- sponded with nutrient-impoverished soils and plants relative to the nutrient levels we measured on fox-free islands. These reductions in nutrient status were coincident with strong shifts in the structure of plant communities. On fox-free islands, plant assemblages were often composed of dense swards of waist-high grasses and sedges, often interspersed with large umbels ( $A n$ gelica lucida and Heracleum lanatum). The biomass of these assemblages was high and $\delta^{15} \mathrm{~N}$ values in vegetation and soil was fairly uniformly enriched, even far from shore (Fig. 4a). In contrast, plant communities on fox-infested islands were less graminoid dominated and had greater cover of low-lying dwarf shrubs (particularly Empetrum nigrum), mosses, lichens, and an assortment of forbs. These differences were reflected in our ordination analysis, where we found highly significant differences in plant species presence/absence across $1-\mathrm{m}^{2}$ sampling plots on fox-free and fox-infested islands, even after distance-from-shore effects were accounted for. Low productivity maritime tundra communities, such as those found on fox-infested islands, characterize cold and wet areas where nitrogen and/or phosphorus limit plant productivity (Chapin et al. 1988, Shaver and Chapin 1991, 1995, Jonasson et al. 1993).

\section{Subsidies, distance from shore, and island size effects}

Sites along the upper edges of beaches and headlands, at the land-sea interface, were notable exceptions to the typically less graminoid dominated assemblages on fox-infested islands. These sites were often characterized by a narrow band of dense L. mollis (interspersed with other graminoid species; Fig. 4). They are often the first areas on fox-infested islands to green up in the spring (J. A. Estes, personal observation). Grass samples from these coastal margins had elevated $\delta^{15} \mathrm{~N}$ values (Fig. 4) indicative of the fact that they were subsidized by windblown sea foam and spray that is high in nitrogen and/or beach wrack that was blown inland (Polis et al. 2004b). Yet, beyond these close-toshore areas, $\delta^{15} \mathrm{~N}$ values in soils and plants on foxinfested islands did not show enrichment. And even within close-to-shore areas (i.e., those that were between 0 and $200 \mathrm{~m}$ from shore), we found significant differences between island types in the magnitude of subsidies, as indicated by $\delta^{15} \mathrm{~N}$ values of soils and plants. Thus, the restriction of graminoid-dominated plant assemblages to the extreme coastal perimeter of many fox-infested Aleutian Islands is likely a consequence of restricted nutrient delivery due to the decimation of seabirds by fox predation.

Like islands in most archipelagos, those in the Aleutian chain vary greatly in size. With the exception of the largest islands $(>2200$ ha), our sampling generally reflected this variation, and allowed us to examine how attributes of island size may influence the extent to which islands are subsidized. Nutrients transported from the ocean to land must traverse a one-dimensional 
island perimeter before being dispersed across a largely two-dimensional land area. As such, the degree to which islands receive subsidies may scale as a power function. Across a range of island sizes, nutrient subsidies coming from the ocean are likely to increase linearly with island perimeter length, and island perimeter-to-area ratio increases as a $1 / 2$ power function of island area. Since similar power functions characterize all allometric relationships, the island size-subsidy relationships in many respects parallel classic arguments regarding the importance of surface to volume ratios in determining rates of material and energy flow across organelles, cells, organs, and entire organisms and their importance to physiological rates (although in this case the theoretical power function is $2 / 3$, Schmidt-Nielsen 1984). For subsidized islands, the exact functional form of the scaling relationship likely depends on the mechanism of transport of nutrients from sea to land, the relative productivity of the adjacent ecosystems, and the geomorphology and topography of the recipient island (Polis et al. 1997, Rose and Polis 1998, Fariña et al. 2003).

On fox-free islands in the Aleutians where seabirds are the primary vector for nutrients moving between systems, $\delta^{15} \mathrm{~N}$ values in soils and grasses scaled positively in relation to island perimeter-to-area ratio. Notably, however, while the magnitude of subsidy increased with island perimeter-to-area ratio, virtually all islands with seabirds showed evidence of marine-based nutrient inputs (Fig. 4). This contrasts to fox-infested islands (Fig. 4), where the eradication of seabird populations by foxes has acted to essentially reset (i.e., reduce) the $y$-intercept of this allometric relationship and to reduce the strength of the allometric function between island size and $\delta^{15} \mathrm{~N}$. Fox introductions appear to have limited the influence of marine subsidies to all but the smallest islands, where wind-borne deposition of marine nutrients may still occur. A more robust test of these ideas would ideally involve a broader sampling of small fox-infested islands. Such small fox-infested islands do not exist, however, because foxes were only introduced onto larger islands that would support viable populations. To circumvent this problem we compared the subset of data collected between 0 and $100 \mathrm{~m}$ from shore between island types. These data were available on all islands, regardless of their size, and one might expect it would be most difficult to detect differences between island types based on this restricted data set if island size effects predominated. Yet, we found significant differences between fox-free and fox-infested islands in many scalar variables (soil phosphorus, $\delta^{15} \mathrm{~N}$ soils, plants, and graminoid biomass) even after island size effects were removed.

In one respect, fox-infested islands are somewhat similar to those studied in the Gulf of California by Polis and Hurd (1996), where only small islands with large perimeter to surface area ratios are heavily subsidized by marine shore drift. Yet, since the general pattern was that $\delta^{15} \mathrm{~N}$ values in soils and plants on foxinfested islands did not show enrichment, subsidies play a smaller role on islands without seabirds in the Aleutians than what may be the case in well-studied islands in hotter and drier locales (Polis and Hurd 1996, Polis et al. 2004b). By disconnecting the nutritional link from sea to land, the introduction of foxes to the Aleutians has reduced or eliminated the significance of the perimeter-to-area allometric relationship that is so clearly evident on the fox-free islands.

The reason that even relatively large fox-free islands with small perimeter-to-area ratios show signs of subsidies is that seabird use and nutrient inputs extend well into upland habitats on many islands (J. L. Maron, J. A. Estes, and D. A. Croll, personal observations). The only exception to this in the islands sampled during our study was on Buldir, the largest fox-free island in the Aleutians. This island is so steep and large that our interior sampling points at the center of the island were at $390 \mathrm{~m}$ above sea level and $>1.5 \mathrm{~km}$ from shore. At these high, cold, and windswept sites, seabird use diminishes and alpine-type vegetation, mostly devoid of graminoids, predominates. Thus, unlike all other foxfree islands we sampled, on Buldir, ${ }^{15} \mathrm{~N}$ values in soil and grass declined significantly with distance from shore.

\section{Fertilization experiments}

Fertilization experiments on a large fox-free island confirmed that vegetation typical of fox-infested islands is strongly nutrient limited. More importantly, these experiments showed that nutrient inputs can drive the community toward a more grass-dominated state, typical of that found on fox-free islands. Other research has similarly found that graminoids are favored under high fertilization conditions (Aerts and Berendse 1988, Wedin and Tilman 1996), although in higher latitude arctic tundra fertilization sometimes favors woody shrubs such as Salix spp. and Betula nana over grasses (Shaver et al. 2001, Mack et al. 2004).

One particularly noteworthy result from our fertilization experiments was that graminoids in general, and L. mollis (the dominant grass on fox-free islands) in particular, respond strongly to high nutrient inputs. Over four years of fertilization and three years of monitoring, there was almost a fourfold increase in L. mollis abundance in high fertilization plots (compared to little gain in abundance in control plots). These results imply that nutrient subsidies strongly contribute to the relative dominance of graminoids on fox-free islands. While we do not know how enriched stands of L. mollis (or graminoids in general) respond to the cessation of nutrient input, as must have occurred shortly after the establishment of foxes on our fox-infested islands, our fertilization experiments clearly showed that under enriched conditions graminoids readily outcompete slower growing dwarf shrubs and forbs. Furthermore, we found that physical disturbance had a net negative rath- 
er than positive effect on plant biomass, implying that the primary mechanism by which seabirds influence vegetation is through nutrient addition, rather than the combined effects of nutrient addition and disturbance, as has been shown in other systems (Hogg and Morton 1983, Vidal et al. 2000). These results are largely consistent with our qualitative observations on fox-free islands. Most upland breeding seabirds on the Aleutian islands are burrow nesters. While nesting density can be extremely high, we never saw large expanses of highly disturbed, completely barren areas that are characteristic of gull colonies on more arid islands.

\section{Subsidies, rainfall, and island productivity}

Our results bolster a growing body of work indicating that island food webs are often strongly subsidized by the movement of nutrients from adjacent productive ocean waters onto less productive land (Polis and Hurd 1996, Anderson and Polis 2004, Polis et al. 2004b). The Aleutian Islands are surrounded by one of the richest and most productive marine environments in the world (McAlister and Favorite 1977). In contrast, terrestrial communities on these islands, while lush due to abundant rainfall and relatively mild winters, are intrinsically nutrient-impoverished. Thus, guano deposited by seabirds is an important source of supplemental nutrients, as has been shown for other oceanic islands throughout the world (Burger et al. 1978, Lindeboom 1984, Bosman and Hockey 1988, Mizutani and Wada 1988, Anderson and Polis 1999, 2004, Garcia et al. 2002). In some island systems, consumer populations are quite responsive to these subsidies. For example, Polis and Hurd (1995, 1996) found that spider populations were 1-3 orders of magnitude larger on small heavily subsidized islands than they were on larger less productive islands. Sánchez-Piñero and Polis (2000) found similarly large effects of subsidies on tenebrionid beetle populations. In arid systems, the effects of nutrient subsidies on plants are often strongly mediated by water availability. Anderson and Polis $(1999,2004)$ found that the plant response to subsidies is much greater during El Niño years compared to normal drier years. In contrast to arid low latitude desert island systems, the Aleutian Islands are cold and wet. Annual rainfall averages between 810 and $1650 \mathrm{~mm}$, with the majority of it occurring during the summer growing season. Although seasonal temperature and sunlight changes likely constrain plant growth on high latitude islands, rainy conditions during the growing season create an environment where nutrient limitation takes precedence over water limitation thereby magnifying the influence of subsidies across the Aleutians.

\section{Soil nitrogen and $\delta^{15} N$ values between island types}

Given the differences in soil and plant $\delta^{15} \mathrm{~N}$ values, and in extractible soil phosphorus between fox-free and fox-infested islands, it was initially surprising that we found no difference in total soil nitrogen between is- land types. The fact that plant tissue had significantly higher concentrations of nitrogen on fox-free vs. foxinfested islands suggests that nitrogen availability and uptake was greater on fox-free than on fox-infested islands, even though accumulation of total nitrogen in the soil was not significantly different between island types. There are two non-exclusive explanations for why we did not detect differences in total soil nitrogen between island types. First, much of the nitrogen in guano is in the form of uric acid, which can be readily converted to gaseous ammonia (Hutchinson 1950). Thus, while deposition and uptake of nitrogen can be high, little of this may be incorporated into the soil. Volatilized ammonia can be dissolved in rain (Freney et al. 1981), and in the windy conditions that prevail in the Aleutians this nitrogen can potentially be redeposited across islands and thus significantly alter island-wide nutrient distribution (Lindeboom 1984). Second, in the persistently rainy and wet Aleutians, some of the nitrogen in guano is likely converted to nitrate and leached from soils. In contrast to labile nitrogen, phosphorus is more stable and is less readily lost from systems than nitrogen (Vitousek 2004). Thus it is not surprising that extractable phosphorus was greater in soil on fox-free than on fox-infested islands.

One intriguing result was that forbs on fox-infested islands had extremely low $\delta^{15} \mathrm{~N}$ values, suggesting that plants on these islands could have been using recently fixed nitrogen (Dawson et al. 2002). If true, nitrogenfixation might partially compensate for the lack of subsidies on these islands. In some high latitude environments, symbiotic cyanobacteria and mosses fix substantial quantities of nitrogen (DeLuca et al. 2002), as is true for cyanobacterium-lichen symbioses. These $\mathrm{N}$ fixers are likely much more abundant on fox-infested than on fox-free islands because lichens and mosses are negatively affected by high nutrient inputs (J. L. Maron, J. A. Estes, and D. A. Croll, unpublished data).

\section{Conclusions}

Many islands throughout the world have had their biological integrity disrupted by introduced predators. Some of the best examples of species extinctions have resulted from the introduction of predators to archipelagos with naïve prey (Savige 1987, Simberloff 1995, Williamson 1996, Whittaker 1998, Courchamp et al. 2003). Yet, while the direct effects of introduced predators on islands are well known, there have been surprisingly few studies that have explored whether these strong direct effects indirectly extend to the base of island food webs to influence plant productivity and community composition, or other ecosystem processes (Cushman 1995). One notable exception is the work by Schoener and Spiller (1999) who demonstrated that islands in the Bahamas with experimentally introduced Anolis lizards had reduced plant leaf damage compared to islands without lizards. Our results show that the ecological effects of fox introductions extended well 
beyond the direct reductions of bird populations. Islands that received foxes were cut off from major inputs of nutrients, with a resulting shift in plant dominance from graminoid-dominated communities to ones with greater abundance of slower growing dwarf shrubs and forbs. Overall species richness was actually higher on fox-infested islands compared to fox-free islands, likely because forbs and dwarf shrubs were released from the strong competitive dominance of graminoids on islands no longer receiving nutrient subsidies. Our sampling also revealed that in the absence of foxes, nutrients vectored in by seabirds are utilized by various higher trophic status consumers in these simple food webs. Whether these subsidies actually lead to increased population sizes of the consumers remains to be seen.

In most terrestrial systems, there are few demonstrations of trophic cascades that have striking community-wide effects (Polis et al. 2000, but see Terborgh et al. 2001). As such, there has been much discussion about whether the dramatic community-wide effects reported for various aquatic systems (e.g., Estes and Palmisano 1974, Carpenter et al. 1985, Power 1990) even should be expected in terrestrial systems (Strong 1992, Oksanen and Oksanen 2000, Paine 2000, Polis et al. 2000, Schmitz et al. 2000). While the debate over trophic cascades has spurred increased research, it may have also had the effect of too narrowly focusing that research on strictly top-down trophic effects of predators (Estes 2005). Over eight years ago, Polis and Strong (1996) made the plea for research that combined examination of consumer-resource dynamics with other factors such as spatial subsidies. They went on to point out that "besides the diversity of direct trophic connections observed in food webs, species in nature are interconnected via a vast number of other direct (e.g., symbiosis) and indirect links that may reinforce or counter direct trophic ones." Results from this study strongly support this sentiment. Food web research would greatly profit by increased focus on quantifying the varied routes by which indirect effects of top predators may permeate interaction web dynamics.

\section{ACKNOWLEDGMENTS}

We dedicate this paper to the late Gary Polis, who provided invaluable advice, enthusiastic support, and inspiration during the planning phases of our work. We thank M. Bricker, M. Burford, J. Donlan, J. Figurski, L. Holsinger, J. Laslett, C. Llewellyn, K. Newton, M. Rica, J. Reichman, R. Richter, A. Rodgers, A. Rose, D. Steller, Jeff Williams, and Jennifer Williams for help with field work and C. Brant and Y. Shimizu for help in the laboratory. Comments by R. Jefferies, D. Gruner, K. Feely, and an anonymous reviewer greatly improved the paper. K. Bell and crew of the M/V Tiglax provided unbelievably good ship support, and V. Byrd, S. Talbot, J. Williams, and the Alaska Maritime National Wildlife Refuge provided essential advice and logistical assistance. This work was supported by NSF grants OPP-9985814 to J. A. Estes and D. A. Croll and NSF OPP-0296208 to J. L. Maron.

\section{Literature Cited}

Aerts, R., and F. Berendse. 1988. The effect of increased nutrient availability on vegetation dynamics in wet heathlands. Vegetatio 76:63-69.

Anderson, W. B., and G. A. Polis. 1998. Marine subsidies of island communities in the Gulf of California: evidence from stable carbon and nitrogen isotopes. Oikos 81:75-80.

Anderson, W. B., and G. Polis. 1999. Nutrient fluxes from water to land: seabirds affect plant nutrient status on Gulf of California islands. Oecologia 118:324-332.

Anderson, W. B., and G. Polis. 2004. Pages 82-95 in G. A. Polis, M. E. Power, and G. R. Huxel, editors. Food webs at the landscape level. University of Chicago Press, Chicago, Illinois, USA.

Ashbrook, F. G., and P. Walker. 1925. Blue fox farming in Alaska. U.S. Department of Agriculture Bulletin 1350.

Bailey, E. P. 1993. Introduction of foxes to Alaskan islandshistory, effects on avifauna, and eradication. United States Department of the Interior, Fish and Wildlife Service, Resource Publication 193, Washington, D.C., USA.

Beard, K. H., K. A. Vogt, and A. Kulmatiski. 2002. Topdown effects of a terrestrial frog on forest nutrient dynamics. Oecologia 133:583-593.

Beckerman, A. P., M. Uriarte, and O. J. Schmitz. 1997. Experimental evidence for a behavior-mediated trophic cascade in a terrestrial food chain. Proceedings of the National Academy of Sciences (USA) 94:10735-10738.

Ben-David, M., R. T. Bowyer, L. K. Duffy, D. D. Roby, and D. M. Schell. 1998. River otter latrines and nutrient dynamics of terrestrial vegetation. Ecology 79:2567-2571.

Black, L. T. 1984. Atka-an ethnohistory of the western Aleutians. Limestone Press, Kingston, Ontario, Canada.

Borer, E. T., E. W. Seabloom, J. B. Shurin, K. E. Anderson, C. A. Blanchette, B. Broitman, S. D. Cooper, and B. S. Halpern. 2005. What determines the strength of a trophic cascade? Ecology 86:528-537.

Bosman, A. L., and P. A. R. Hockey. 1988. The influence of seabird guano on the biological structure of rocky intertidal communities on islands off the west coast of southern Africa. South African Journal of Marine Science 7:61-68.

Brett, M. T., and C. R. Goldman. 1996. A meta-analysis of the freshwater trophic cascade. Proceedings of the National Academy of Sciences (USA) 93:7723-7726.

Brooks, J. L., and S. I. Dodson. 1965. Predation, body size, and the composition of plankton. Science 150:28-35.

Burger, A. E., H. J. Lindeboom, and A. J. Williams. 1978. The mineral and energy contributions of guano of selected species of birds to the Marion Island terrestrial ecosystem. South African Journal of Antarctic Research 8:59-70.

Bustamante, R. H., G. M. Branch, and S. Eekhout. 1995. Maintenance of an exceptional intertidal grazer biomass in South Africa: subsidy by subtidal kelps. Ecology 76:23142329.

Byrd, G. V. 1984. Vascular vegetation of Buldir Island, Aleutian Islands, Alaska compared to another Aleutian Island. Arctic 37:37-48

Byrd, G. V., and R. H. Day. 1986. The avifauna of Buldir Island, Aleutian Islands, Alaska. Arctic 39:109-118.

Byrd, G. V., J. L. Trapp, and C. F. Zeillemaker. 1994. Removal of introduced foxes: a case study in restoration of native birds. Pages 317-321 in Transactions of the 59th North American Wildlife and Natural Resource Conference. Wildlife Management Institute, Washington, D.C., USA.

Carpenter, S. R., and J. F. Kitchell. 1993. The trophic cascade in lake ecosystems. Cambridge University Press, Cambridge, UK.

Carpenter, S. R., J. F. Kitchell, and J. R. Hodgson. 1985. Cascading trophic interactions and lake productivity. BioScience 35:634-639. 
Chapin, F. S., III, N. Fetcher, K. Kielland, K. R. Everett, and A. E. Linkins. 1988. Productivity and nutrient cycling of Alaskan tundra: enhancement by flowing soil water. Ecology 69:693-702.

Courchamp, F., J. L. Chapuis, and M. Pascal. 2003. Mammal invaders on islands: impact, control and control impact. Biological Reviews 78:347-383.

Croll, D. L., J. L. Maron, J. A. Estes, E. M. Danner, and G. V. Byrd. 2005. Introduced predators transform subarctic islands from grassland to tundra. Science 307:1959-1961.

Cushman, J. H. 1995. Ecosystem-level consequences of species additions and deletions on islands. Pages 135-147 in P. M. Vitousek, L. L. Loope, and H. Adsersen, editors. Islands: biological diversity and ecosystem function. Ecological studies. Volume 115. Springer-Verlag, Berlin, Germany.

Dall, W. H. 1874. Notes on the avifauna of the Aleutian Islands, especially those west of Unalaska. Proceedings of the California Academy of Sciences 5:270-281.

Darwin, C. 1859. The origin of species by means of natural selection. John Murray, London, UK.

Dawson, T. E., S. Mambellli, A. H. Plamboeck, P. H. Templer, and K. P. Tu. 2002. Stable isotopes in plant ecology. Annual Review of Ecology and Systematics 33:507-559.

DeAngelis, D. L. 1992. Dynamics and nutrient cycling and food webs. Chapman and Hall, New York, New York, USA.

DeLuca, T. H., O. Zackrisson, M.-C. Nilsson, and A. Sellstedt. 2002. Quantifying nitrogen-fixation in feather moss carpets of boreal forests. Nature 419:917-920.

Duffy, J. E. 2002. Biodiversity and ecosystem function: the consumer connection. Oikos 99:201-219.

Dyer, L. A., and D. K. Letourneau. 1999. Trophic cascades in a complex, terrestrial community. Proceedings of the National Academy of Sciences (USA) 96:5072-5076.

Estes, J. A. 2005. Carnivory and connectivity in kelp forest interaction webs. Pages 61-81 in J. C. Ray, K. H. Redford, R. S. Steneck, and J. Berger, editors. Large carnivores and the conservation of biodiversity. Island Press, Washington, D.C., USA.

Estes, J. A., and D. O. Duggins. 1995. Sea otters and kelp forests in Alaska: generality and variation in a community ecological paradigm. Ecological Monographs 65:75-100.

Estes, J. A., and J. Palmisano. 1974. Sea otters: their role in structuring nearshore communities. Science 185:10581060.

Estes, J. A., M. T. Tinker, T. M. Williams, and D. F. Doak. 1998. Killer whale predation on sea otters linking oceanic and nearshore environments. Science 282:473-476.

Fariña, J. M., S. Salazar, K. P. Wallem, J. D. Witman, and J. C. Ellis. 2003. Nutrient exchanges between marine and terrestrial ecosystems: the case of the Galapagos sea lion Zalophus wollebaeckii. Journal of Animal Ecology 72:873887.

Flecker, A. S. 1996. Ecosystem engineering by a dominant detritivore in a diverse tropical stream. Ecology 77:18451854.

Freney, J. R., J. R. Thompson, and O. T. Denmead. 1981. Ammonia volatilization. Ecological Bulletin 33:291-302.

Furness, R. W. 1991. The occurrence of burrow-nesting among birds and its influence on soil fertility and stability. Zoological Symposium 63:53-67.

Garcia, L. V., T. Maranon, F. Ojeca, L. Clemente, and R. Redondo. 2002. Seagull influence on soil properties, chenopod shrub distribution, and leaf nutrient status in semiarid Mediterranean islands. Oikos 98:75-86.

Gard, L. M., Jr. 1977. Geologic history. Pages 13-34 in M. L. Merritt and R. G. Fuller, editors. The environment of Amchitka Island, Alaska. National Technical Information Service, U.S. Department of Commerce, TID-26712. Springfield, Virginia, USA.
Gomez, J. M., and R. Zamora. 1994. Top-down effects in a tritrophic system: parasitoids enhance plant fitness. Ecology 75:1023-1030.

Gruner, D. S. 2004. Attenuation of top-down and bottom-up forces in a complex terrestrial community. Ecology 85: 3010-3022.

Hairston, N. G., F. E. Smith, and L. B. Slobodkin. 1960. Community structure, population control, and competition. American Naturalist 94:421-425.

Halaj, J., and D. H. Wise. 2001. Terrestrial trophic cascades: how much do they trickle? American Naturalist 157:262281

Hogg, E. H., and J. K. Morton. 1983. The effects of nestling gulls on the vegetation and soil of islands in the Great Lakes. Canadian Journal of Botany 61:3240-3254.

Hunter, M. D., and P. W. Price. 1992. Playing chutes and ladders: heterogeneity and the relative roles of bottom-up and top-down forces in natural communities. Ecology 73: 724-732.

Huryn, A. D. 1998. Ecosystem-level evidence for top-down and bottom-up control of production in a grassland stream system. Oecologia 115:173-183.

Hutchinson, G. E. 1950. Survey of existing knowledge of biogeochemistry 3. The biogeochemistry of vertebrate excretion. Bulletin of the American Museum of Natural History 96 .

Huxel, G. R., and K. McCann. 1998. Food web stability: the influence of trophic flows across habitats. American Naturalist 152:460-469.

Jefferies, R. L. 1999. Herbivores, nutrients and tropic cascades in terrestrial environments. Pages 301-330 in H. Olff, V. K. Brown, and R. H. Drent, editors. Herbivores: between plants and predators. 38th Symposium of the British Ecological Society. Blackwell Scientific Publications, Oxford, UK.

Jonasson, S., M. Havstrom, M. Jensen, and T. V. Callaghan. 1993. In situ mineralization of nitrogen and phosphorus of arctic soils after perturbations simulating climatic change. Oecologia 95:179-186.

Kitchell, J. F., D. E. Schindler, B. R. Herwig, D. M. Post, M. H. Olson, and M. Oldham. 1999. Nutrient cycling at the landscape scale: the role of diel foraging migrations by geese at the Bosque del Apache National Wildlife Refuge, New Mexico. Limnology and Oceanography 44:828-836.

Lindeboom, H. J. 1984. The nitrogen pathway in a Penguin rookery. Ecology 65:269-277.

Mack, M. C., E. A. G. Schuur, M. S. Bret-Harte, G. R. Shaver, and F. S. Chapin, III. 2004. Ecosystem carbon storage in arctic tundra reduced by long-term nutrient fertilization. Nature 431:440-443.

Marquis, R. J., and C. J. Whelan. 1994. Insectivorous birds increase growth of white oak through consumption of leafchewing insects. Ecology 75:2007-2014.

McAlister, W. B., and F. Favorite. 1977. Oceanography. Pages 331-352 in M. L. Merritt and R. G. Fuller, editors. The environment of Amchitka Island. NTIS, U.S. Department of Commerce, TID-26712. Springfield, Virginia, USA.

McLaren, B. E., and R. O. Peterson. 1994. Wolves, moose and tree rings on Isle Royale. Science 266:1555-1558.

Menge, B. A. 1995. Indirect effects in marine rocky intertidal interaction webs: patterns and importance. Ecological Monographs 65:21-74.

Menge, B. A. 1997. Detection of direct versus indirect effects: were experiments long enough? American Naturalist 149:802-823.

Menge, B. A. 2000. Top-down and bottom-up community regulation in marine rocky intertidal habitats. Journal of Experimental Marine Biology and Ecology 250:257-289.

Micheli, F. 1999. Eutrophication, fisheries, and consumerresource dynamics in marine pelagic ecosystems. Science 285:1396-1398. 
Mizutani, H., and E. Wada. 1988. Nitrogen and carbon isotope ratios in seabird rookeries and their ecological implications. Ecology 69:340-349.

Moore, J. C., K. S. McCann, H. Setälä, and P. C. de Ruiter. 2003. Top-down is bottom-up: does predation in the rhizosphere regulate aboveground dynamics? Ecology 84: 846-857.

Moran, M. D., and L. E. Hurd. 1998. A trophic cascade in a diverse arthropod community caused by a generalist arthropod predator. Oecologia 113:126-132.

Mueller-Dombois, D., and H. Ellenberg. 1974. Aims and methods of vegetation ecology. Wiley, New York, New York, USA.

Murie, O. J. 1959. Fauna of the Aleutian Islands and Alaska Peninsula. North American Fauna 61:1-406.

Nadelhoffer, K., G. Shaver, B. Fry, A. Giblin, L. Johnson, and $\mathrm{R}$. McKane. 1996. ${ }^{15} \mathrm{~N}$ natural abundances and $\mathrm{N}$ use by tundra plants. Oecologia 107:386-394.

Oksanen, L., and T. Oksanen. 2000. The logic and realism of the hypothesis of exploitation ecosystems. American Naturalist 155:703-723.

Pace, M. L., J. J. Cole, S. R. Carpenter, and J. F. Kitchell. 1999. Trophic cascades revealed in diverse ecosystems. Trends in Ecology and Evolution 14:483-488.

Paine, R. T. 1966. Food web complexity and species diversity. American Naturalist 100:65-73.

Paine, R. T. 1980. Food webs: linkage, interaction strength, and community infrastructure. Journal of Animal Ecology 49:667-685.

Paine, R. T. 2000. Phycology for the mammalogist: marine rocky shores and mammal-dominated communities-how different are the structuring processes? Journal of Mammalogy 81:637-648.

Polis, G. A., W. B. Anderson, and R. D. Holt. 1997. Toward an integration of landscape and food web ecology: the dynamics of spatially subsidized food webs. Annual Review of Ecology and Systematics 28:289-316.

Polis, G. A., and S. D. Hurd. 1995. Extraordinarily high spider densities on islands: flow of energy from the marine to terrestrial food webs and the absence of predation. Proceedings of the National Academy of Sciences (USA) 92: 4382-4386.

Polis, G. A., and S. D. Hurd. 1996. Linking marine and terrestrial food webs: allochthonous input from the ocean supports high secondary productivity on small islands and coastal land communities. American Naturalist 147:396423.

Polis, G. E., M. E. Power, and G. R. Huxel, editors. $2004 a$. Food webs at the landscape level. University of Chicago Press, Chicago, Illinois, USA.

Polis, G. A., F. Sánchez-Piñero, P. T. Stapp, W. B. Anderson, and M. D. Rose. $2004 b$. Trophic flows from water to land: marine input affects food webs on islands and coastal ecosystems worldwide. Pages 200-216 in G. A. Polis, M. E. Power, and G. R. Huxel, editors. Food webs at the landscape level. University of Chicago Press, Chicago, Illinois, USA.

Polis, G. A., and D. R. Strong. 1996. Food web complexity and community dynamics. American Naturalist 147:813846.

Polis, G. A., D. R. Strong, G. R. Huxel, A. L. W. Sears, and J. L. Maron. 2000. When is a trophic cascade a trophic cascade? Trends in Ecology and Evolution 15:473-475.

Polis, G. A., and K. O. Winemiller, editors. 1996. Food webs: integration of patterns and dynamics. Chapman and Hall, New York, New York, USA.

Post, D. M., J. P. Taylor, J. F. Kitchell, M. H. Olson, D. E. Schindler, and B. R. Herwig. 1998. The role of migratory waterfowl as nutrient vectors in managed wetlands. Conservation Biology 12:910-920.
Power, M. E. 1990. Effects of fish in river food webs. Science 250:811-814.

Power, M. E., W. J. Matthews, and A. J. Stewart. 1985. Grazing minnows, piscivorous bass, and stream algae: dynamics of a strong interaction. Ecology 66:1448-1456.

Riley, R. H., and R. L. Jefferies. 2004. Subsidy dynamics and global change. Pages 410-433 in G. A. Polis, M. E. Power, and G. R. Huxel, editors. Food webs at the landscape level. University of Chicago Press, Chicago, Illinois, USA.

Ripple, W. J., E. J. Larsen, R. A. Renkin, and D. W. Smith. 2001. Trophic cascades among wolves, elk and aspen on Yellowstone National Park's northern range. Biological Conservation 1022:227-234.

Roemer, G. W., C. J. Donlan, and F. Courchamp. 2002. Golden eagles, feral pigs and insular carnivores: how exotic species turn native predators into prey. Proceedings of the National Academy of Sciences (USA) 99:791-796.

Rose, M. D., and G. A. Polis. 1998. The distribution and abundance of coyotes: the effects of allochthonous food subsidies from the sea. Ecology 79:998-1007.

Sánchez-Piñero, F., and G. A. Polis. 2000. Bottom-up dynamics of allochthonous direct and indirect effects of seabirds on islands. Ecology 81:3117-3132.

SAS. 2001. SAS software. Version 8.2. SAS Institute, Cary, North Carolina, USA.

Savige, J. A. 1987. Extinction of an island forest avifauna by an introduced snake. Ecology 68:660-668.

Schindler, D. E., and S. C. Lubetkin. 2004. Using stable isotopes to quantify material transport in food webs. Pages 25-42 in G. A. Polis, M. E. Power, and G. R. Huxel, editors. Food webs at the landscape level. University of Chicago Press, Chicago, Illinois, USA.

Schindler, D. E., and M. D. Scheuerell. 2002. Habitat coupling in lake ecosystems. Oikos 98:177-189.

Schindler, D. E., M. D. Scheuerell, J. W. Moore, S. M. Gende, T. B. Francis, and W. J. Palen. 2003. Pacific salmon and the ecology of coastal ecosystems. Frontiers in Ecology and the Environment 1:31-37.

Schmidt-Nielsen, K. 1984. Scaling. Why is animal size so important? Cambridge University Press, Cambridge, UK.

Schmitz, O. J. 1998. Direct and indirect effects of predation and predation risk in old-field interaction webs. American Naturalist 151:327-342.

Schmitz, O. J. 2003. Top predator control of plant biodiversity and productivity in an old field ecosystem. Ecology Letters 6:156-163.

Schmitz, O. J., P. Hambäck, and A. P. Beckerman. 2000. Trophic cascades in terrestrial systems: a review of the effect of top predator removals on plants. American Naturalist 155:141-153.

Schoener, T. W., and D. A. Spiller. 1999. Indirect effects in an experimentally staged invasion by a major predator. American Naturalist 153:347-358.

Shaver, G. R., S. Bret-Harte, M. H. Jones, J. Johnstone, L. Gough, J. Laundre, and F. S. Chapin, III. 2001. Species composition interacts with fertilizer to control long-term change in tundra productivity. Ecology 82:3163-3181.

Shaver, G. R., and F. S. Chapin, III. 1991. Production/biomass relationships and element cycling in contrasting arctic vegetation types. Ecological Monographs 61:1-31.

Shaver, G. R., and F. S. Chapin, III. 1995. Long-term responses to factorial NPK fertilizer treatment by Alaskan wet and moist tundra sedge species. Ecography 18:259275.

Shurin, J. B., E. T. Borer, E. W. Seabloom, K. Anderson, C. A. Blanchette, B. Broitman, S. D. Cooper, and B. S. Halpern. 2002. A cross-ecosystem comparison of the strength of trophic cascades. Ecology Letters 5:785-791.

Simberloff, D. 1995. Introduced species. Pages 323-336 in W. A. Nierenberg, editor. Encyclopedia of environmental 
biology. Volume 2. Academic Press, San Diego, California, USA.

Spiller, D. A., and T. W. Schoener. 1994. Effects of top and intermediate predators in a terrestrial food web. Ecology 75:182-196.

Stapp, P., and G. A. Polis. 2003. Marine resources subsidize insular rodent populations in the Gulf of California, Mexico. Oecologia 134:496-504.

Strong, D. R. 1992. Are trophic cascades all wet? The redundant differentiation in trophic architecture of high diversity ecosystems. Ecology 73:747-754.

SYSTAT. 2000. SYSTAT for Windows: statistics. Version 10.0. SPSS, Chicago, Illinois, USA.

Terborgh, J., L. Lopez, V. Nunez, M. Rao, G. Shahabuddin, G. Orihuela, M. Riveros, R. Ascanio, G. H. Adler, T. D. Lambert, and L. Balbas. 2001. Ecological meltdown in predator-free forest fragments. Science 294:1923-1926.

U.S. Fish and Wildlife Service. 2004. Beringian Seabird Colony Catalog-computer database. U.S. Fish and Wildlife Service, Migratory Bird Management, Anchorage, Alaska, USA.

Van Bael, S. A., J. D. Brawn, and S. K. Robinson. 2003. Birds defend trees from herbivores in a Neotropical forest canopy. Proceedings of the National Academy of Sciences (USA) 14:8304-8307.
Vanni, M. J. 1996. Nutrient transport and recycling by consumers in lake food webs: implications for algal communities. Pages 81-95 in G. A. Polis and K. O. Winemiller, editors. Food webs: integration of patterns and dynamics. Chapman and Hall, New York, New York, USA.

Vanni, M. J., and D. L. Findlay. 1990. Trophic cascades and phytoplankton community structure. Ecology 71:921-937.

Vanni, M. J., and C. D. Layne. 1997. Nutrient recycling and herbivory as mechanisms in the "top-down" effect of fish on algae in lakes. Ecology 78:21-40.

Vidal, E., F. Medail, T. Tatoni, and V. Bonnet. 2000. Seabirds drive plant species turnover on small Mediterranean islands at the expense of native taxa. Oecologia 122:427-434.

Vitousek, P. M. 2004. Nutrient cycling and limitation. Princeton University Press, Princeton, New Jersey, USA.

Wedin, D. A., and D. Tilman. 1996. Influence of nitrogen loading and species composition on the carbon balance of grasslands. Science 274:1720-1723.

Whittaker, R. J. 1998. Island biogeography. Oxford University Press, Oxford, UK.

Williams, J., G. Byrd, and N. Konyukhov. 2003. Whiskered Auklets, Aethia pygmaea, foxes, humans, and how to right a wrong. Marine Ornithology 31:175-180.

Williamson, N. 1996. Biological invasions. Chapman and Hall, London, UK.

\section{APPENDIX A}

A description of the preliminary sampling conducted in August 2001 (Ecological Archives M076-001-A1).

\section{APPENDIX B}

Results of nested ANOVAs testing for differences in soil and plant nutrients, stable isotopes, and dwarf shrub biomass (Ecological Archives M076-001-A2).

\section{APPENDIX C}

Results of nested ANCOVA testing for effects of island type, island size, and island identity nested within island type on extractable soil phosphorus, soil, grass, and forb (i.e., Achillea borealis) $\delta^{15} \mathrm{~N}$, and graminoid biomass (Ecological Archives M076-001-A3).

\section{APPENDIX D}

Repeated-measures ANOVA results for the first fertilization experiment conducted on Adak Island (Ecological Archives M076-001-A4).

\section{APPENDIX E}

Repeated-measures ANOVA results for the second fertilization experiment conducted on Adak Island (Ecological Archives M076-001-A5). 